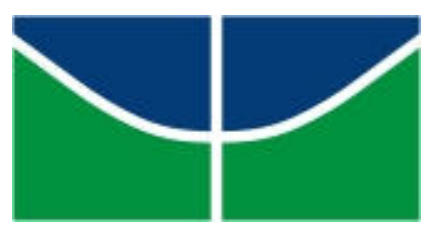

UNIVERSIDADE DE BRASÍLIA

INSTITUTO DE CIÊNCIAS HUMANAS

DEPARTAMENTO DE GEOGRAFIA

LOTEAMENTOS CLANDESTINOS NO DISTRITO FEDERAL - A QUESTÃO DO SETOR HABITACIONAL PONTE DE TERRA, GAMA - DF

Sands Xavier da Silva Pereira

Orientadora: Professora Doutora Marília Luiza Peluso

Brasília

2008 
Universidade de Brasília

Instituto de Ciências Humanas

Departamento de Geografia

LOTEAMENTOS CLANDESTINOS NO DISTRITO FEDERAL - A QUESTÃO DO SETOR HABITACIONAL PONTE DE TERRA, GAMA - DF

Sands Xavier da Silva Pereira

Orientadora: Professora Dr. ${ }^{a}$ Marília Luiza Peluso

Brasília

2008 
Universidade de Brasília

Instituto de Ciências Humanas

Departamento de Geografia

\title{
LOTEAMENTOS CLANDESTINOS NO DISTRITO FEDERAL - A QUESTÃO DO SETOR HABITACIONAL PONTE DE TERRA, GAMA - DF
}

\author{
Sands Xavier da Silva Pereira
}

Monografia de Prática de Pesquisa de Campo II submetida ao Departamento de Geografia do Instituto de Ciências Humanas da Universidade de Brasília como parte dos requisitos necessários para a obtenção do grau Bacharelado em Geografia.

Banca Examinadora:

Dr. ${ }^{a}$ Marília Luiza Peluso (Orientadora)

Professora do Departamento de Geografia - Universidade de Brasília - UnB

Msc. Gilberto Alves de Oliveira Junior

Professor do Departamento de Geografia - Universidade de Brasília - UnB

Msc. Benjamin de Lacerda Junior

Professor do Grupo Educacional Fortium e Faculdade Cenecista de Brasília

Brasília-DF, 05 de dezembro de 2008 


\section{FICHA CATALOGRÁFICA}

PEREIRA, Sands Xavier da Silva. Loteamentos Clandestinos no Distrito Federal - A Questão do Setor Habitacional Ponte de Terra, Gama - DF. 59 p. (GEA - IH - UnB, Bachareal em Geografia, 2008). Monografia de Prática e Pesquisa de Campo II. Universidade de Brasília. Instituto de Ciências Humanas. Departamento de Geografia.

I. Questão habitacional

II. Loteamentos clandestinos

III. Setor Habitacional Ponte de Terra

\section{REFERÊNCIA BIBLIOGRÁFICA}

PEREIRA, Sands Xavier da Silva. Loteamentos Clandestinos no Distrito Federal - A Questão do Setor Habitacional Ponte de Terra, Gama - DF. Monografia de Prática e Pesquisa de Campo II. Universidade de Brasília. Instituto de Ciências Humanas. Departamento de Geografia. Brasília, 2008. 59 p.

\section{CESSÃO DE DIREITOS}

Autoria: Sands Xavier da Silva Pereira

Título: Loteamentos Clandestinos no Distrito Federal - A Questão do Setor Habitacional Ponte de Terra, Gama - DF.

Grau: Bacharel, 2008.

É concedida à Universidade de Brasília permissão para reproduzir cópias desta monografia e, ainda, emprestar e/ou vender cópias, desde que sejam destinadas para propósitos acadêmicos ou científicos. $\mathrm{O}$ autor reserva outros direitos de publicação e nenhuma parte desta monografia pode ser reproduzida sem a devida autorização, por escrito, por ele mesmo. 
“O espaço é a morada do homem, mas pode ser também sua prisão" Milton Santos 


\section{AGRADECIMENTOS}

Agradeço primeiramente aos meus familiares, pais Edvard e Almem, meus irmãos Heldher e Gleiderson por dedicarem apoio para a realização deste trabalho.

Aos professores do curso de Geografia da UnB, em especial à professora Marília Luiza Peluso que, devido às suas aulas me despertou um interesse especial pela Geografia Urbana e o estudo sobre Brasília e também aos professores que compõe a banca, Benjamin Lacerda Junior e Gilberto Alves de Oliveira Junior.

Aos amigos e aos colegas da geografia e de outros cursos que conheci nas aulas, no K3, movimento estudantil, viagens e festas. Aos amigos, Fabrício, Rico-Jones, Podrinho, Léo, Rogério, Renata, Gazela, Fabi, Morceguet, Flores, Guilherme, Baiano, Mac-Mac . 


\section{A Cidade Não Pára}

Em cada rua um rosto, em cada rosto a mesma angústia Apenas um em 1 milhão a ter a mesma dúvida Será que vale esperar, será que tanto faz?

Será uma peça a mais dessa máquina voraz? Não há tempo há perder As engrenagens não podem parar Não há tempo pra pensar Não há tempo pra sofrer Cidade não pára, cidade não pára, cidade não pára Cidade cresce para todos os lados, devorando e engolindo todos os espaços

Será que existe um lugar, onde se vive em paz? Sufocado, acuado, encurralado, pôr todos os lados que a gente vai

Ninguém cai fora daqui, será que o caos não satisfaz?

Não há tempo há perder

As engrenagens não podem parar

Não há tempo pra pensar

Não há tempo pra sofrer

Cidade não pára, cidade não pára, cidade não pára A cidade não tem tempo para entender, a cidade não tem tempo para sonhar

A cidade não tem medo para perder, a cidade não tem tempo para matar

Cidade não pára, cidade não pára, cidade não pára

(Inocentes) 


\section{RESUMO}

Este trabalho tem como objetivo compreender a questão habitacional de Brasília e dos loteamentos clandestinos que vem modificando o espaço urbano. Nessa modificação temos o surgimento de sérios problemas urbanos e ambientais, o que pode comprometer a qualidade de vida da cidade já que se modifica o espaço urbano sem qualquer planejamento. A pesquisa também levanta a questão do Setor Habitacional Ponte de Terra no Gama-DF, que está sendo criado a partir de uma série de loteamentos clandestinos feitos em uma área que há alguns anos tinha como destinação o uso rural. Durante o processo em que se realizou a pesquisa, quando se fez uma caracterização físico-ambiental apareceram alguns problemas, como o fato do setor estar em duas Áreas de Proteção de Mananciais (APMs), comprometendo a qualidade das águas para abastecimento público. A hipótese levantada é de que a falta da atuação do Estado para solucionar a questão habitacional deu origem ao surgimento de loteamentos clandestinos, que em decorrência disso surgem novos problemas, principalmente os ambientais.

Palavras-chaves: Questão habitacional. Loteamentos clandestinos. Setor Habitacional Ponte de Terra. 


\section{LISTA DE FIGURAS}

Figura 1: Gráfico comparativo de classe de renda domiciliar média - p.32

Figura 2: Mapa de Localização da RA II - Gama - p.33

Figura 3: Mapa de Localização do Setor Habitacional Ponte de Terra - p. 34

Figura 4: Mapa de delimitação do Setor Habitacional Ponte de Terra - p. 35

Figura 5: Análise multitemporal da ocupação do território - p.38

Figura 6: Mapa Geológico Simplificado da região do Distrito Federal - p. 39

Figura 7: Mapa de localização das APMs Ponte de Terra e Córrego Olho D’água - p.44

\section{LISTA DE FOTOS}

Foto 1: Lote com solo exposto praticamente sem cobertura vegetal - p.41

Foto 2: Presença de espécies nativas e principalmente de gramíneas invasoras - p.42

Foto 3: Mata de galeria do lado esquerdo e vereda do lado direito - p.42

Foto 4: Água comprometida próximo a captação Ponte de Terra I - p.46

Foto 5: Pastagem próxima à vereda e mata de galeria - p.47

Foto 6: Presença de lixo próximo ao Córrego Ponte de Terra - p.47

Foto 7: Poço artesiano - p.48

Foto 8: Via pavimentada - p.49

Foto 9: Falta de pavimentação nas principais vias que cortam o setor - p.49

Foto 10: Falta de pavimentação nos loteamentos - p.50

Foto 11: Anúncio de venda de lotes no Setor Habitacional Ponte de Terra - p.51 


\section{LISTA DE SIGLAS}

CAESB - Companhia de Saneamento Ambiental do Distrito Federal

CODEPLAN - Companhia de Planejamento do Distrito Federal

NOVACAP - Companhia Urbanizadora da Nova Capital

PDL - Plano Diretor Local

PDOT - Plano Diretor de Ordenamento Territorial

SEDUH - Secretaria de Estado de Desenvolvimento Urbano e Habitação, hoje SEDUMA.

SEDUMA - Secretaria de Estado de Desenvolvimento Urbano e Meio Ambiente

TERRACAP - Companhia Imobiliária do Distrito Federal 


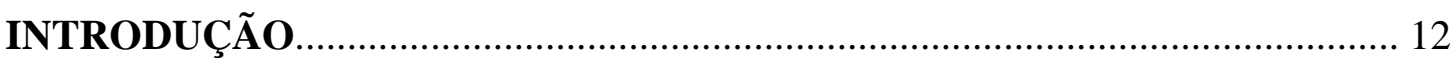

PROCEDIMENTOS METODOLÓGIGOS...................................................... 15

1. FALTA DE MORADIAS DESDE O INÍCIO DA CONSTRUÇÃO................ 18

2. A QUESTÃO DOS LOTEAMENTOS CLANDESTINOS EM BRASÍLIA... 25

3. SETOR HABITACIONAL PONTE DE TERRA .......................................... 31

3.1. A Região Administrativa do Gama - RA II.......................................... 31

3.2. Setor Habitacional Ponte de Terra........................................................... 34

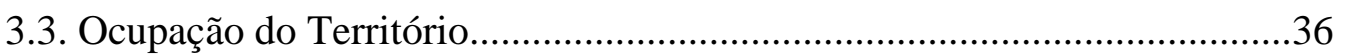

3.4. Caracterização Físico-Ambiental.............................................................. 39

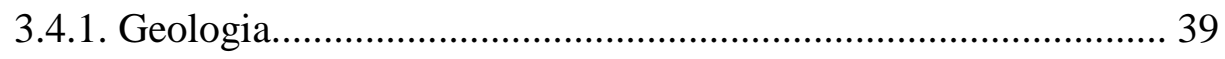

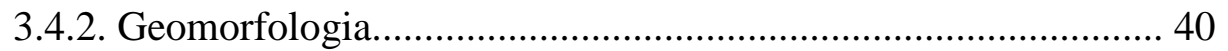

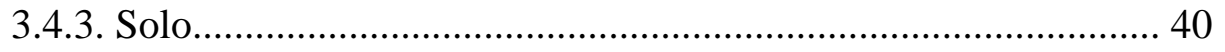

3.4.4. Vegetação......................................................................... 41

3.4.5. Recursos Hídricos................................................................... 43

3.4.5.1. Captações Ponte de Terra I, II e III..............................45

3.4.5.2. Captação Olho D’ Água..............................................45

3.4.5.3. Contaminação Hídrica.................................................. 45

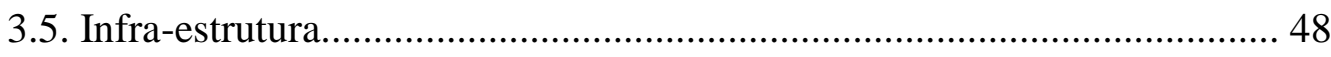

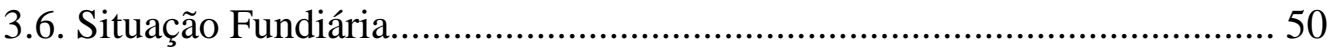

3.7. Proposta do Governo Para o Setor Habitacional....................................... 51

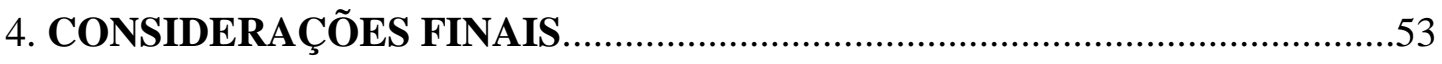

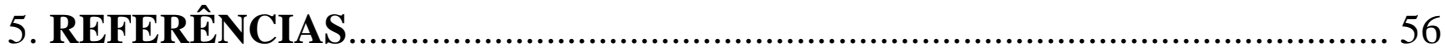

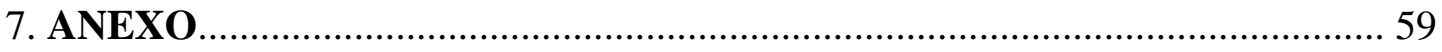




\section{INTRODUÇÃO}

No período da construção de Brasília $^{1}$, a busca por mão-de-obra para trabalhar na construção da nova capital se dava por todo o Brasil. Já no início da construção havia o problema da falta de moradia e os trabalhadores se acomodavam na Cidade Livre (Núcleo Bandeirante) e adjacências dos canteiros de obras espalhados pelo Plano Piloto. Antes mesmo da inauguração da nova capital, já havia uma reivindicação por moradia por parte dos trabalhadores e era evidente que não havia moradia para todos no Plano Piloto, lugar que foi destinado principalmente aos funcionários públicos graduados.

$\mathrm{Na}$ falta de moradias e em decorrência das lutas populares por ela, criou-se em 1958, Taguatinga, que se tornou a primeira cidade-satélite do Distrito Federal, localizada cerca de $20 \mathrm{~km}$ do Plano Piloto e logo em seguida foram criadas as cidadessatélites do Gama e Sobradinho em 1960, o Guará (1966) e Ceilândia (1970), e outras cidades-satélites no decorrer dos anos. Desde o início, deu-se uma expansão periférica de novos espaços urbanos e uma segregação sócio-espacial promovida pelo próprio Estado, como a exclusão da maior parte dos trabalhadores para longe do centro de Brasília.

Pela ótica de que o centro possui um valor da terra mais elevado, surge um problema que é praticamente impossível pessoas de baixa renda conseguirem morar no centro em uma moradia própria ou alugada. A população de média renda também tem dificuldade, pois os preços dos imóveis estão muito elevados, o que faz com que busquem novos espaços para moradia, muitos não conseguem pagar um aluguel ou vendem seus imóveis para obter uma renda e buscam lugares um pouco mais distantes

\footnotetext{
${ }^{1}$ Brasília é "entendida como o Distrito Federal urbano, isto é, formada por um centro que é o Plano Piloto e por sua periferia, as cidades-satélites". (PAVIANI, 1987, p. 14)
} 
do centro. Nesse sentido as classes de baixa e média renda foram e são protagonizadores do processo de expansão urbana de Brasília.

O contexto do alto custo da habitação que dificulta o acesso à moradia, levou também ao surgimento de loteamentos clandestinos, nos quais, principalmente os destinados às classes mais baixas, observa-se a falta de condições adequadas de moradia, falta de serviços básicos de infra-estrutura urbana, acessos restritos a serviços públicos (saúde, educação, transporte coletivo) e dificuldade de acesso aos locais de interesses (lazer, trabalho, residência) devido às distâncias.

No processo de expansão urbana a questão dos loteamentos tem um grande destaque, principalmente quando se trata dos loteamentos clandestinos, que ao solucionar o problema da falta de moradia tanto para a classe média, quanto para as classes mais baixas, vem afetando negativamente a qualidade de vida de toda a cidade por falta de planejamento, principalmente quando se trata de questões urbanísticas e ambientais.

Percebe-se a ausência do Estado na hora de atuar, seja fiscalizando, regulamentando e/ou ofertando novas áreas para a expansão urbana. Nesse sentido o Estado é um agente menos presente, enquanto os proprietários fundiários, promotores imobiliários e os grupos sociais têm liberdade para modificar o espaço urbano mesmo com restrições, cabendo ao Estado apenas algumas correções cabíveis para minimizar os impactos causados.

No contexto de ocupação desordenada, está a apropriação das terras rurais para a expansão urbana por alguns agentes, motivados principalmente por interesses individuais em detrimento dos interesses coletivos, dentre os quais podemos inserir os 
loteadores de terras particulares e os loteadores de terras públicas, os chamados "grileiros".

Os problemas levantados neste trabalho são a falta de moradias em Brasília ao longo dos anos, a questão dos loteamentos clandestinos e problemas ambientais que podem gerar.

O objetivo geral da pesquisa é compreender a questão habitacional de Brasília e dos loteamentos clandestinos, para verificar como o Setor Habitacional Ponte de Terra do Gama-DF se insere nesse contexto, e os impactos ambientais que a ocupação do setor possa estar causando devido a uma ineficiente atuação do Poder Público. Como objetivo específico encontra-se fazer uma caracterização físico-ambiental da área do Setor Habitacional Ponte de Terra, para dar um suporte no entendimento sobre a questão ambiental do local e fazer uma abordagem de como o setor insere no PDOT/1997 e a sua proposta de revisão que está em andamento para verificar as propostas do GDF para o setor. A hipótese levantada é de que a falta de atuação do Estado para solucionar a questão habitacional deu origem ao surgimento de loteamentos clandestinos que está causando danos ambientais. 


\section{PROCEDIMENTOS METODOLÓGICOS}

A primeira etapa consistiu em realizar uma pesquisa bibliográfica a respeito da questão habitacional em Brasília a fim de compreender como se desenvolveu o processo de ocupação da cidade. Em seguida fez-se um levantamento bibliográfico e documental, centrado na questão dos loteamentos no DF, buscou-se informações em publicações acadêmicas e de órgãos oficiais como a CODEPLAN, SEDUMA, bem como uma pesquisa no "Relatório final da CPI da Grilagem de terras públicas do Distrito Federal(1995)" para consubstanciar o entendimento e reflexões acerca da referida questão.

A segunda etapa subsidiou a obtenção de informações sobre a RA II - Gama e o Setor Habitacional Ponte de Terra no Gama-DF. Este embora legalmente ainda não existe, vem sendo contemplado no conjunto das preocupações sobre loteamentos clandestinos no DF na proposta de revisão do PDOT. Nesta direção, foi levantado nos documentos técnicos de revisão do PDOT informações sobre a proposta de legalização do setor, da mesma forma que em outras pesquisas em publicações de órgãos públicos, do projeto de lei do PDOT e do PDL do Gama (2007), para compreender a questão fundiária, política e ambiental na área de estudo.

A terceira etapa consistiu em obter uma seqüência de imagens de satélites do Distrito Federal de diversos períodos para ser feita uma análise multitemporal e elaborar mapas com técnicas da Cartografia, Sistemas de Informações Geográficas (SIG) e de Sensores Remoto, dando destaque a utilização dos softwares Arcview 3.3 e Envi 4.5, além de utilizar o software gráfico CorelDRAW 12. 
A quarta etapa consistiu em fazer saídas de campo no Setor Habitacional Ponte de Terra, para verificar a ocupação nas APMs do Córrego Olho D’água, do Córrego Ponte de Terra. Fez-se observações diretas para verificar como estão ocorrendo os impactos ambientais mais visíveis nas bacias e elucidar melhor a questão da ocupação e da infra-estrutura urbana.

A quinta etapa consistiu em uma verificação da caracterização físico-ambiental da área de estudo de acordo com as informações obtidas nas saídas de campo, além de utilizar referência no banco de dados em SIG do Sistema de Informações Territoriais Urbanas do Distrito Federal (SITURB) e consultas a textos de especialistas. Esta etapa tem por objetivo verificar o processo de ocupação ao longo dos anos, apresentar o recorte do local de estudo através dos mapas e além de auxiliar na caracterização físicoambiental, como, auxiliar a obtenção de informações sobre a geologia, geomorfologia, solo, vegetação, recursos hídricos, além fazer uma apresentação onde está localizado o setor nas APMs do Córrego Ponte de Terra e Córrego Olho D’Água.

A partir de alguns problemas verificados nas etapas anteriores a cerca da questão sobre os recursos hídricos, foi necessário a obtenção de informações sobre os recursos hídricos nas duas bacias nas publicações da CAESB sobre a contaminação hídrica e relacionar os impactos ambientais visíveis através das saídas de campo.

Uma etapa do trabalho não foi possível realizar, que era uma entrevista estruturada com os moradores. A entrevista consistia em perguntas sobre a questão fundiária, infra-estrutura, renda dos moradores, acessibilidade, ambiental. Esta etapa não foi possível realizar por dificuldades de realizar uma entrevista concisa, com uma quantidade razoável de moradores, já que parte não deseja responder esse tipo de pesquisa, além de dificuldades de acessar as casas, pois muitas se encontram em 
“condomínios" fechados, além da dificuldade de encontrar moradores na rua, já que o Setor Habitacional Ponte de Terra compreende uma grande área e ainda pouco ocupada.

A pesquisa para fins metodológicos encontra-se divida em três capítulos, sendo os dois primeiros para estabelecer um referencial teórico para embasamento da proposta do trabalho que é tratar da questão da falta de moradias e do surgimento dos loteamentos clandestinos em Brasília, e o terceiro capítulo enfoca na questão da área de estudo que é o Setor Habitacional Ponte de Terra no Gama-DF, onde por meio de um conjunto de informações será possível fazer um recorte de seu passado, presente e uma perspectiva futura. 


\section{1 - FALTA DE MORADIAS DESDE O INÍCIO DA CONSTRUÇÃO}

O processo de urbanização em Brasília se inicia na década de 50 e desde o início havia o problema das "ocupações irregulares" que resultaram nas invasões, já que não havia definido os locais de moradias.

No início as moradias dos pioneiros eram precárias, os trabalhadores viviam nos acampamentos construídos próximos aos canteiros de obras pelas empresas construtoras.

Segundo RIBEIRO, (1991, p.32) os acampamentos foram a solução para a questão habitacional utilizado no período da construção de Brasília. Nesses acampamentos segundo o Censo de 1959 viviam 28.010 habitantes, o que representava 43,5\% da população de 64.314 habitantes na época. O restante se dividia nos núcleos provisórios com a população de 17.761 habitantes, núcleos estáveis com a população de 6.277 habitantes e na zona rural com 12.256 habitantes.

Dos acampamentos existentes, alguns eram controlados pelas construtoras e ou pela NOVACAP, ou então surgiam acampamentos espontâneos chamados de favelas.

A estrutura oferecida pelos acampamentos inicialmente não supria as necessidades e as demandas de consumo, serviços, etc. A Cidade Livre, surgiu como grande aglomerado, que tinha como função prover a demanda por produtos e serviços de que necessitava a população, já que isso não era suprido nos acampamentos e nem mesmo pelos assentamentos próximos, como, Luziânia, Formosa, Planaltina e Brazlândia.

No caso dos canteiros de obras que se localizam dentro das cidades ou próximos a redes urbanas estruturadas onde já existe um fator de aglomeração, o canteiro se relaciona com este fator dentro do conceito de 
utilização do valor de uso complexo. No caso da construção de Brasília, a própria hierarquização existente no interior dos acampamentos das construtoras, que não satisfaziam às necessidades dos operários, fez com que surgisse um espaço onde as relações de mercado pudessem dar vazão a essas necessidades. A Cidade Livre surge, assim, em função da inexistência de um fator de aglomeração próximo ao canteiro de obras e dos acampamentos oficiais. (QUINTO; IWAKAMI, 1991, p.61)

O governo se preocupava com o crescimento da Cidade Livre, já que era a principal alternativa de local de moradia para parte dos imigrantes. O governo desejava controlar o crescimento e proibiu construções na Cidade Livre, uma das causas pelas quais surgiram invasões ao redor dos acampamentos.

\begin{abstract}
Já no final de 1958, proibidas novas construções na então chamada Cidade Livre, proliferaram invasões e construções irregulares que, ao lado dos acampamentos de obras, se constituíam nas alternativas de habitação para os trabalhadores que afluíram à cidade. Surgem, então, as primeiras cidades-satélites. Jogando para a periferia o candango e isolando Brasília para a burocracia estatal que começava a chegar, o governo apenas afastava o problema habitacional, recriando-o na medida em que definia, junto à segregação espacial, a desigualdade de acesso aos recursos públicos e aos equipamentos. (JACCOUD, 1991, p.147)
\end{abstract}

A Cidade Livre foi criada em 1956 e tinha prazo para deixar de existir após a inauguração de Brasília em 1960, coisa que não aconteceu. Os moradores seriam encaminhados principalmente para a cidade-satélite de Taguatinga que foi inaugurada em 1958, mas grande parte da população residente na Cidade Livre permaneceu.

A Cidade Livre foi fixada em 1961 com o nome de Núcleo Bandeirante a partir da luta dos movimentos populares organizados principalmente pelos comerciantes do local. O caso do Núcleo Bandeirante foi um dos poucos casos onde a população resistiu à remoção promovida pelo Poder Público, mas algumas invasões nas proximidades foram removidas para outros locais.

Segundo PAVIANI (2005, p.6-7), em 1959, um ano antes da inauguração do Plano Piloto o Distrito Federal contava com a população de 64.314 habitantes e ao ser 
inaugurado, contava com 141.742 habitantes. Houve uma corrente migratória devido à demanda por operários pela construção civil, além da transferência da Capital e mudanças do Congresso Nacional, Tribunais e ministérios.

Após a inauguração de Brasília o processo de migração continuou. $\mathrm{O}$ principal destino da população que chegou e a população que era removida das invasões foram às cidades-satélites de Taguatinga, Sobradinho e Gama, que estavam constituídas na época. Ao mesmo tempo em que removia invasões e se concedia moradias, o governo segregava física e socialmente, a população:

\begin{abstract}
Com efeito, em um primeiro momento, o governo segregou física e socialmente as classes populares nas distantes e mal-equipadas cidadessatélites, desenvolvendo ao mesmo tempo uma política de controle social desta população, por meio da distância que separa os núcleos satélites do Plano Piloto (centro de decisões) e pelo traçado deste núcleo. Tal desenho, com ruas retilíneas e longas, com edifícios sem abertura para os espaços públicos, em várias de suas partes formando becos, que funcionam como depósito de lixo, e espaços públicos exageradamente amplos e áridos, criou um traçado urbano bem diverso do arranjo espacial dos assentamentos erradicados. (GOUVÊIA, 1991, p.84)
\end{abstract}

Durante este período mesmo com as ações do Estado para remover as invasões, elas continuaram e surgiram movimentos populares que reivindicavam moradia em Brasília.

O problema da falta de moradias atingiu as várias classes, sejam os imigrantes em busca de emprego, como operários e funcionários públicos. Os últimos foram melhor contemplados, parte obtendo moradia na região central.

A questão da moradia para funcionários públicos se expressou no período de 1960 e 1964, sobretudo por meio das invasões de apartamentos, que durante os primeiros anos da nova capital fizeram parte de seu cotidiano de lutas sociais. Elas objetivaram, e de fato conseguiam, levar o poder público a agilizar a solução para o problema. Apesar de o governo recorrer à Justiça e conseguir habitualmente a reintegração dos imóveis ocupados, com o despejo dos invasores, a questão política criada exigia solução. (JACCOUD, 1991, p.150) 
GOUVÊIA (1991, p.82) observa a clara intenção de construir o Plano-Piloto para abrigar funcionários públicos mais graduados e também políticos, devido a discrepância das condições de moradias no centro de Brasília que possui um padrão muito melhor do que era ofertado aos demais trabalhadores nas cidades-satélites com um padrão inferior.

Segundo Jaccoud, as diversas lutas pela ocupação e apropriação do espaço urbano também resultaram na configuração do espaço urbano de Brasília:

\footnotetext{
Profundamente articulada à questão da forma com que se deu a ocupação e apropriação do espaço urbano da cidade pelos diversos grupos sociais e de sua gestão pública, as lutas por moradia e seus condicionantes não só repercutiram intensamente no cenário social e político da cidade na época, como tiveram profunda influência na constituição do perfil urbano de Brasília. (JACCOUD, 1991, p.151)
}

Desde o início da construção, ainda nos acampamentos havia segregação, seja desde pequenos privilégios entre os níveis hierárquicos nos acampamentos até na ocupação das cidades-satélites pelas classes sociais definindo o arranjo sócio-espacial de Brasília.

Segundo GOUVEIA (1991, p.88), em Brasília chegou a ocorrer uma política de não-oferta de moradias com o intuito de conter a migração, mas o que aconteceu foi o surgimento de favelas e sub-locação de lotes unifamiliares. A política de não-oferta não obteve êxito, pois a migração continuou.

Na década de 60, o governo criou o Guará I, e início da década de 70 criou o Guará II e a Ceilândia, esta última originada a partir da Campanha de Erradicação de Invasões (CEI), promovida pelo GDF (Governo do Distrito Federal). Esse programa tinha como objetivo retirar as favelas e os acampamentos das construtoras, onde viviam 
cerca de 82 mil pessoas. Foram cadastrados todos os barracos adjacentes ao Núcleo Bandeirante e posteriormente transferidos para a Ceilândia.

Na década de 80, as invasões e as favelas continuaram se expandindo e houve também uma política habitacional voltada à classe média. Ao final da década foi criado o Setor Sudoeste para a classe média, que fazia parte do projeto Brasília Revisitada, de Lucio Costa. Para erradicar as invasões, favelas e sublocações criou-se a cidade-satélite de Samambaia, também em 1989. Dando continuidade à oferta de moradias para as classes mais baixas na década de 90, o GDF criou as cidades-satélites do Riacho Fundo, Santa Maria, Recanto das Emas, São Sebastião, e outras.

\begin{abstract}
O período contemporâneo, que inclui os últimos 15 anos, se entrelaça com ações para a autonomia política e administrativa, revelando-se crucial para o surgimento de verdadeira metrópole terciária e quaternária: limpeza de áreas faveladas do Plano Piloto, transferência dos moradores dos chamados "fundos de quintal" das cidades-satélites, algo revelador da segregação com periferização sócioespacial. Houve também aumento significativo de assentamentos como Riacho Fundo 1 e 2, Santa Maria, Recanto das Emas, novo Paranoá, expansões em Ceilândia - Setor Ó - e setores anexados como a quadra 18, em Sobradinho, Vila Buriti em Planaltina, Vila São José, em Brazlândia. Nesse período acorrem ações violentas da polícia militar para a desconstituição da favela Estrutural, mas os moradores obtiveram, sob protestos, sua consolidação, apoiados por políticos e deputados distritais. A consolidação da favela foi sucedida pela sua ampliação, com a fixação de novos favelados, totalizando mais de 40 mil pessoas. Próximo a Paranoá, também estimulada por políticos, surge e se expande a favela Itapuã, hoje com mais de 50 mil habitantes, que padecem com a falta de infra-estrutura, serviços urbanos mínimos e, como em todas as "expansões", falta de postos de trabalho. (PAVIANI, 2005, p.11-12)
\end{abstract}

Ocorreu um processo de periferização em Brasília, principalmente por conta da luta por moradias. As pessoas que resistem a sair de certos locais ocupados hoje, pouco diferem dos locais ocupados no passado, tendo praticamente os mesmo problemas, como falta de infra-estrutura, equipamentos públicos, transporte público precário e às vezes inexistente. 
No processo de expansão dos núcleos urbanos de Brasília temos hoje os loteamentos clandestinos que vem dando nova configuração territorial. Esses loteamentos tem tido destaque na imprensa, nas ações do Poder Público, do acompanhamento da população e principalmente aos interessados diretos pelos loteamentos.

Peluso destaca um novo período que traça uma organização da ocupação do território.

\begin{abstract}
As grandes linhas da história da ocupação oficial do território do DF terminam aqui, quando a população do DF atingiu 1.598.2 habitantes. Mas, há outro processo de ocupação em curso, a princípio muito oculto e que aos poucos vai adquirindo visibilidade, até tornar-se o problema mais sério do momento atual. Trata-se da apropriação irregular e clandestina de terras, que não deve ser confundido com as invasões das populações de baixa renda, pois o processo é outro, visto que envolve compra e venda de lotes, registros irregulares em cartório e populações de todos os tipos de renda, mas principalmente média e alta renda. (PELUSO, 2003, p.19)
\end{abstract}

Os loteamentos clandestinos diferenciam-se das invasões das populações de baixa renda. Esses loteamentos são feitos através da venda e compra de terras, seja de terras particulares ou terras públicas. Este contexto é um pouco mais complexo, já que envolve outros agentes, também uma demanda específica por determinados tipos de habitação, dentre outros fatores.

Segundo Paviani, o período que compreende 1979 e início dos anos 90, e o período contemporâneo,

[...]houve a ampliação do processo polinucleado de povoamento e a desorganização na ocupação do território por condomínios privados. Muitas dessas ocupações são irregulares ou ilegais, ocupando APAs (Áreas de Proteção Ambiental), nascentes de riachos, como em Vicente Pires, área de matas ciliares, pendentes de morros como no Grande Colorado - tudo ao arrepio das leis ambientais e esforço demagógicos de alguns deputados distritais. (PAVIANI, 2005, p.12) 
Mesmo com a construção de novos núcleos urbanos onde destinou variados tipos de moradias para as diversas classes de renda da população, hoje um dos problemas são os loteamentos clandestinos, e consigo outros problemas são criados. 


\section{2 - A QUESTÃO DOS LOTEAMENTOS CLANDESTINOS EM BRASÍLIA}

Desde o início da construção de Brasília como foi tratado inicialmente neste trabalho, colocou-se em foco o problema da falta de moradias e como conseqüência o surgimento de invasões ou ocupações ilegais em áreas urbanas e em áreas rurais. Hoje um problema para Brasília são os loteamentos ilegais, aqueles que não são regularizados. Segundo a SEDUMA (2007), estima-se que residam cerca de 533.578 habitantes, ou seja, 22\% da população do DF vivem nos “condomínios".

Considera-se loteamento urbano aquele que tem como destinação a formação de novos núcleos populacionais como bairros, vilas ou cidades, conforme a Lei Federal $\mathrm{n}^{\circ}$ 6.766/79. Já o loteamento rural no Distrito Federal, é aquele que possui módulos de no mínimo 2 (dois) hectares, além de ter como finalidade a exploração extrativista agrícola, pecuária ou agro-industrial. Caso o loteamento não tenha finalidade rural, independentemente do tamanho e da localização é considerado urbano. O que considera o imóvel rural $^{2}$ é a destinação de acordo com o Estatuto da Terra, lei $n^{\circ} 4.504$, de novembro de 1964.

Segundo o Relatório da CPI da Grilagem de Terras Públicas do Distrito Federal (1995), os primeiros loteamentos clandestinos figuram em 1956, período em que era intensa a corrida pela desapropriação de terras em Brasília. Os loteamentos clandestinos passaram a ter destaque no noticiário principalmente a partir da década de 90 pelos graves problemas fundiários, urbanísticos e ambientais.

\footnotetext{
2،“'Imóvel Rural', o prédio rústico, de área contínua qualquer que seja a sua localização que se destina à exploração extrativa agrícola, pecuária ou agro-industrial, quer através de planos públicos de valorização, quer através de iniciativa privada;" Lei Federal n 4.504 de 30 de novembro de 1964.
} 
Para relatório da CPI da Grilagem (1995), os loteadores para tentar fugir da Lei Federal $n^{\circ} 6.766 / 79$, realizavam loteamentos com lotes de 02 (dois) hectares, tamanho mínimo de lotes rurais que a lei permite, achando assim que estariam efetuando loteamentos rurais e não urbanos, para os quais não precisariam de aprovação do Distrito Federal, acreditando na impunidade, já que a fiscalização do Distrito Federal não poderia agir. Mas essa tentativa de lotear não encontrou respaldo, já que praticamente todos os loteamentos tinham finalidade urbana. Outro método que os loteadores buscavam, era a grilagem de terras públicas, quando falsificavam documentos de áreas que foram desapropriadas pelo governo em cartórios de cidades do interior do Goiás para buscar o título dessas propriedades e iniciar os loteamentos.

Mesmo com o título de propriedade verdadeiro, legalmente para criar um loteamento necessitaria de aprovação do Poder Público. São necessários que se cumpram requisitos urbanísticos e da comprovação da terra a ser loteada, estar conforme a Lei Federal $n^{\circ}$ 6.766/79, cumprir os artigos dispostos no PDOT, além da exigência de Estudo de Impacto Ambiental e Relatório de Impacto Ambiental EIA/RIMA, para que seja possível o licenciamento ambiental.

Os loteamentos são voltados tanto para as classes mais baixas, quanto para as classes mais altas. Também verificam loteamentos de baixa densidade e de alta densidade. Os loteamentos de baixa densidade muitas vezes são ocupados pela classe média, os de alta densidade pelas classes de baixa renda. Os loteamentos são feitos tanto em áreas públicas arrendadas ao uso agrícola e parcelamentos de chácaras, quanto a partir de áreas privadas rurais e por fim, por meio de grilagem em terras públicas. 
A grande expansão dos loteamentos clandestinos se dá pela fraca atuação do Poder Público e acaba dando liberdade de atuação a especuladores imobiliários e proprietários fundiários. Como escreve Malagutti,

\begin{abstract}
A experiência tem demonstrado que, quando a Administração Pública não intervém com presteza e competência na oferta de moradias para as diversas categorias de renda, ou quando não propicia os meios para o problema ser sanado pela iniciativa privada, os loteadores clandestinos intervêm e acarretam maiores prejuízos à sociedade como um todo. (MALAGUTTI, 1999, p. 57)
\end{abstract}

Diante do histórico, têm-se que os principais agentes que atuam na questão da moradia são os proprietários fundiários, promotores imobiliários, o Estado e os grupos sociais excluídos, segundo a definição de Corrêa e correlacionando com o que se presencia em Brasília.

“Os proprietários fundiários atuam no sentido de obterem maior renda fundiária de suas propriedades" (CORRÊA, 1995, p.16). Se interessam na conversão da terra rural para urbana, a ampliação da cidade, já que a terra urbana é mais valorizada. Os proprietários fundiários no Distrito Federal exercem também poder no Estado indireta ou diretamente, interferindo no processo de definição das leis de uso do solo no zoneamento urbano com participação política devido a vitórias em cargos eletivos. Na periferia é visível a transformação do espaço rural em espaço urbano, e o diferencial obtido entre a produção agrícola e com a venda de terras dado a sua valorização pela demanda sobre habitação, estimula ainda mais o lucrativo surgimento de loteamentos clandestinos.

Promotores imobiliários - é o "conjunto de agentes que realiza, parcial ou totalmente as seguintes operações:" (CORRÊA, 1995, p.19) de incorporação; financiamento, estudo técnico, construção ou produção física do imóvel, 
comercialização. Em Brasília temos o Estado e as empresas imobiliárias e incorporadoras como promotores imobiliários.

Estado - é o principal agente de ordenamento espacial. Ele tem uma atuação político-administrativa, regulamenta o uso solo, controla as vendas e os preços da terra com a Terracap, regulamenta leis e normas para o uso do solo, regulamenta localizações específicas de uso, promove investimentos em infra-estrutura, serviços públicos, etc.

Grupos sociais excluídos verificados em Brasília são: as classes mais baixas, e também uma parcela da classe média que tem dificuldade de morar no centro. As classes mais baixas foram contempladas em alguns períodos com moradias regulares nas cidades-satélites, mas com relação à questão dos loteamentos ainda vivem à margem da lei, sofrendo com a falta de infra-estrutura urbana, transporte público, serviços públicos básicos, etc. Uma parte da classe média considera-se excluída, pois não conseguem manter um padrão de vida no Plano Piloto, mas que têm a necessidade de morar em outros locais, mas esbarra na falta de moradias. Essa falta de moradias principalmente próxima ao centro, faz com que a classe média opte por morar em loteamentos clandestinos, já que os preços são mais acessíveis que os regularizados.

É visível que Brasília tem problemas na oferta de moradias que atenda às várias classes e seus interesses. A Terracap é a grande empresa imobiliária do GDF, detentora de grande parte das terras públicas do DF e responsável pela venda, submetida à gestão do governo, mas não a deixa livre dos demais especuladores fundiários e proprietários fundiários.

O processo pelo qual a maior parte das terras são oferecidas no mercado pela Terracap é licitação pública, mediante a realização de leilões. Isto dá à terra um caráter especulativo, porque as empresas maiores, com maior disponibilidade de capital - as incorporadoras - compram-na como uma 
parcela do valor associada à esfera da circulação, onde se busca principalmente, a intensidade dos fluxos na realização da mercadoria.

Como o governo do Distrito Federal possui a capacidade de dispor sobre onde e quando criará novas áreas residenciais, coloca essas terras no mercado por um preço de monopólio, oriundo da diferença entre o preço de mercado e o preço regulador do mercado de terras. Este preço regulador é estabelecido arbitrariamente pelo próprio Estado, devido ao monopólio afirmado anteriormente. (CAMPOS, 1991, p. 110).

Alguns argumentos têm destaque na questão da proliferação dos loteamentos, no monopólio do estoque das terras pelo governo, na falta de condições financeiras para adquirir um imóvel regularizado e os imóveis clandestinos são mais baratos, como descreve Malagutti:

Um dos argumentos utilizados para explicar a proliferação dos loteamentos clandestinos é que a iniciativa urbanizadora governamental, adotada pela Terracap, não atendeu à demanda de imóveis da população local. Devido a isso, muitos cidadãos acusam o governo de ter mantido o seu estoque de terras públicas, em detrimento do atendimento às carências populacionais.

Os dados analisados apóiam parcialmente essas alegações e desnudam outro aspecto da questão: a grande falha governamental foi não ter percebido, a tempo que a Terracap não tinha condições de, sozinha, atender a essa demanda, utilizando parâmetros de preços que alcançassem os diversos níveis da população. Caso assumisse abertamente essa carência, poderia ter propiciado meios para aliar-se à iniciativa privada no processo de urbanização, dentro de critérios que a lei e o interesse público impusessem. Por diversas ocasiões, constatou-se que num mesmo período e numa mesma localidade os preços obtidos nas licitações da Terracap eram bem superiores aos do mercado imobiliário legal (lotes particulares, anteriormente comprados da própria Terracap), advindo daí a conotação pública de que a Terracap se constitui em especuladora do mercado de terras públicas.

Com relação ao mercado ilegal de terras oferecidas pelos loteadores clandestinos, as comparações tornam-se mais difíceis. A princípio, os preços dos imóveis clandestinos eram muito mais baratos que os lotes regulares, tendo em vista a própria ilegalidade. Mais ainda, porque imóveis ilegais eram vendidos sem nenhuma infra-estrutura básica, enquanto os loteamentos efetuados pelo Poder Público, via de regra possuem infra-estrutura e são servidos por equipamentos urbanos e comunitários, na forma que a lei exige. (MALAGUTTI, 1999, p. 67- 68)

Como os lotes clandestinos são mais baratos, dependendo do tipo de empreendimento e atraem as pessoas que não têm condições financeiras para comprar 
um lote regularizado, essa compra é muitas vezes a solução, além daqueles que comparam esperando a regularização do terreno para obter uma maior renda com uma futura venda. Muitos dos compradores poderão, no entanto, sofrer com a informalidade de morar em um loteamento clandestino, como a falta de um endereço, falta de infraestrutura urbana básica, acesso a serviços públicos como, delegacias, postos de saúde, escolas, transporte coletivo e outros, mas tem a vantagem de comprar um lote mais barato.

Hoje a questão dos loteamentos clandestinos se tornou muita problemática, pois a posição do governo é de que há necessidade de regularização dessas áreas, principalmente onde há um maior adensamento populacional e maior consolidação, onde é impossível a remoção dos moradores e das edificações, e que está gerando problemas por conta desse desordenamento da ocupação de terras, principalmente ambientais.

Dentro de todo esse contexto do processo de ocupação de Brasília e do surgimento dos loteamentos clandestinos, o trabalho abordará adiante a questão do Setor Habitacional Ponte de Terra no Gama-DF, que surgiu a partir de uma área destinada a lotes que tinham finalidade atividades rurais, e hoje se tornou um aglomerado de loteamentos urbanos. 


\section{3 - SETOR HABITACIONAL PONTE DE TERRA}

\section{1 - A Região Administrativa do Gama - RA II}

O Setor Habitacional Ponte de Terra está localizado na Região Administrativa do Gama - RA II, que foi fundada em abril de 1960, mas sua data oficial de inauguração é 12 de outubro de 1960. A proposta era abrigar algumas famílias transferidas de uma invasão na Barragem do Paranoá e posteriormente abrigar moradores da Vila Planalto, Vila Amauri e do Setor de Indústria de Taguatinga.

A Região Administrativa do Gama localiza-se no sudoeste do Distrito Federal, conforme indica a figura 2. Faz limite com os municípios do Estado de Goiás, Novo Gama ao Sul e o Santo Antônio do Descoberto ao oeste, além das Regiões Administrativas, Santa Maria a Leste, Recanto das Emas e Núcleo Bandeirante ao norte.

A Região Administrativa possui uma área total de 276,34 km², sendo 15,37 km² de área urbana e 260,97 km² de área rural. A área urbana é dividida em 06 (seis) setores: Norte, Sul, Leste, Oeste, Central e Indústria. A área rural é formada pelo Núcleo Rural Monjolo, Colônia Agrícola Ponte Alta e Córrego Crispim, Núcleo Rural Ponte Alta de Baixo e Ponte Alta Norte e Alagado.

O Gama possui uma população de 130.580 habitantes, sendo 7.836 residem na área rural. A renda média familiar é de $\mathrm{R} \$ 1.558,00$ segundo PDAD (2004). As famílias residentes têm uma renda pouco inferior à renda média do Distrito Federal, conforme indica a figura 1 . 
Figura 1 - Gráfico comparativo de classe de renda domiciliar média

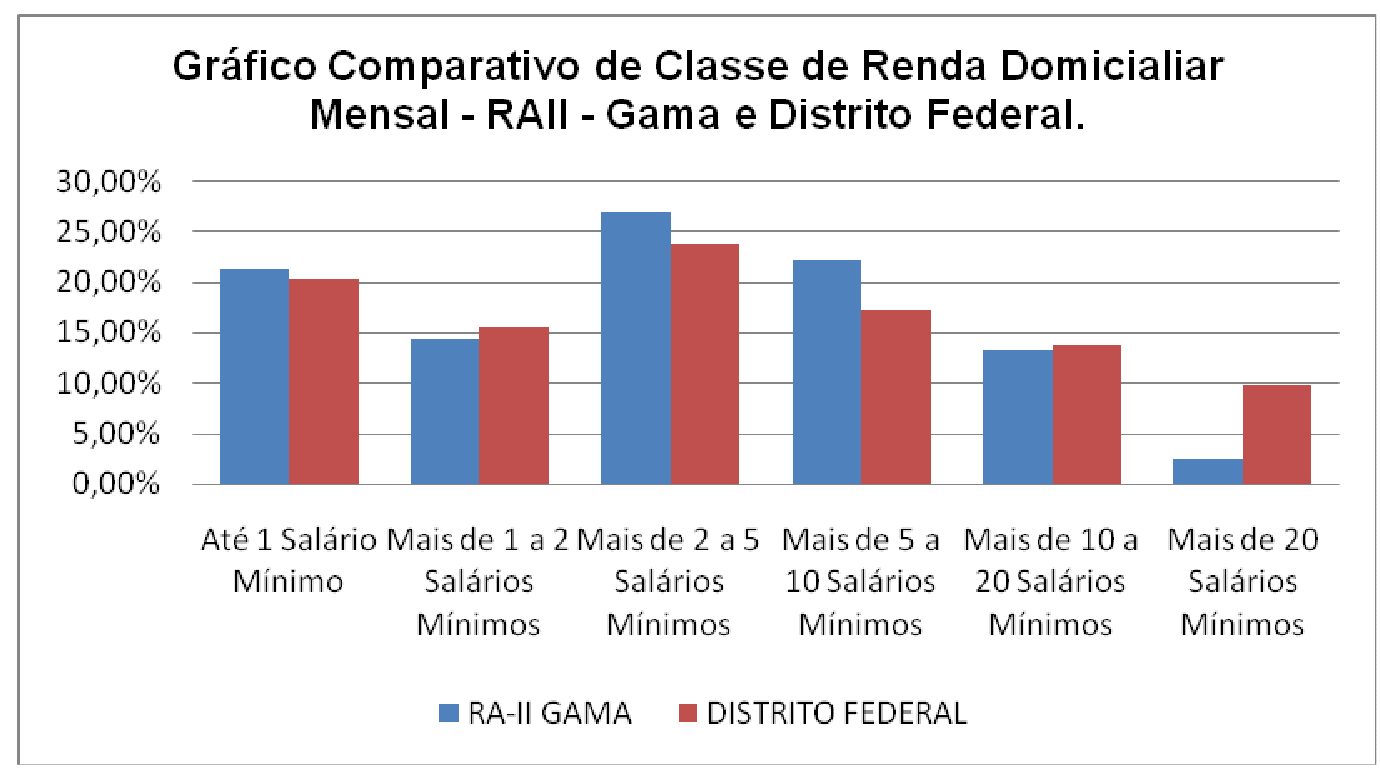

Fonte: PDAD, 2004.

A RA II - Gama possui 13 loteamentos urbanos clandestinos, o que representa 4\% do total de loteamentos do Distrito Federal. A população residente nos loteamentos da cidade é de 10.505 habitantes, o que representa $2 \%$ da população residente nos loteamentos clandestinos por Região Administrativa (SEDUH, 2004). 
Figura 2 - Mapa de Localização da RA II - Gama

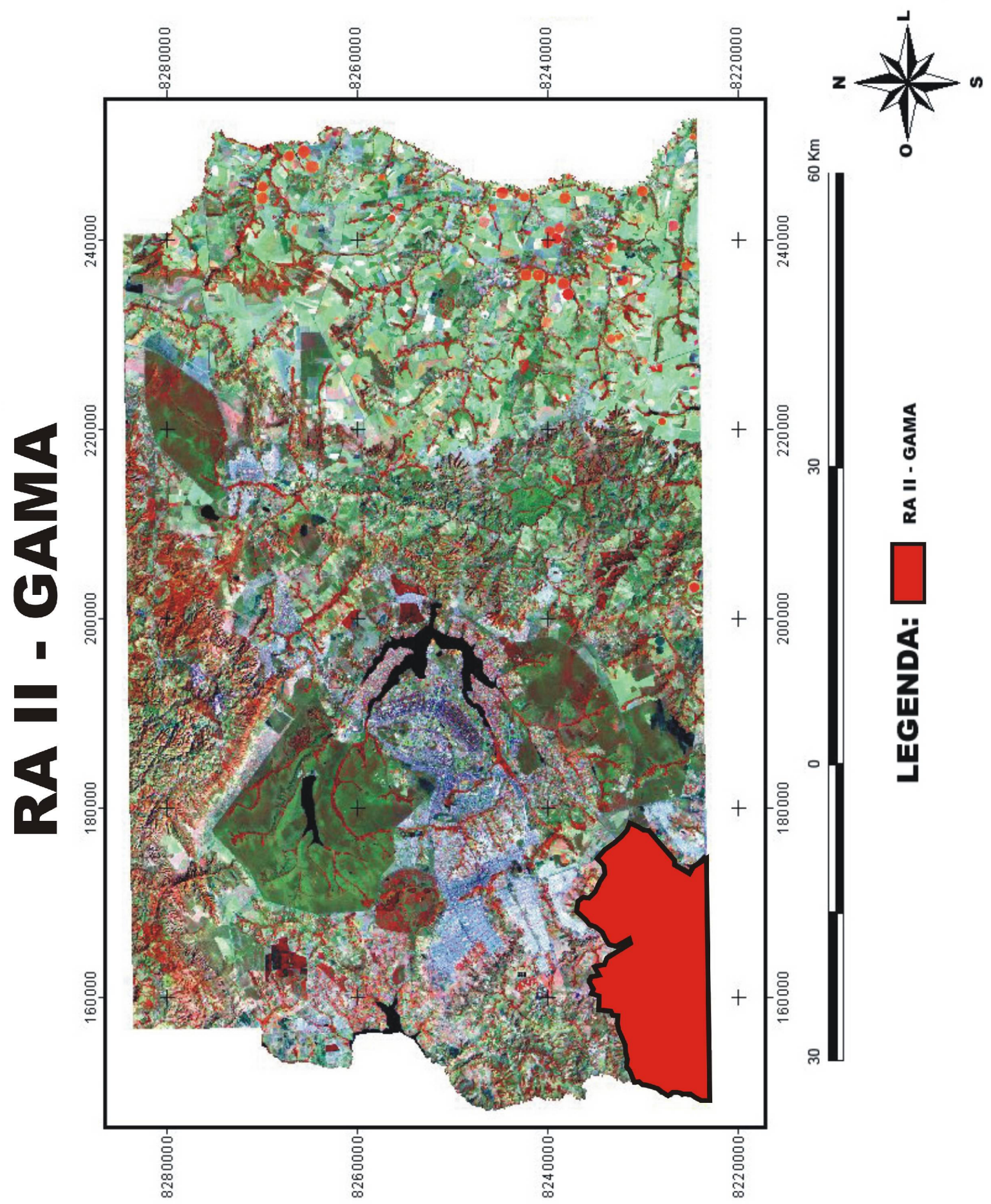

Projeto cartográfico: Sands Xavier da Silva Pereira, 2008. Projeção Cartográfica Universal de Mercator (UTM) ZONA 23S. DATUM SAD-69. Imagem coletada pelo satélite Landsat. Composição 4:3:2 


\section{2 - Setor Habitacional Ponte de Terra}

O Setor Habitacional Ponte de Terra está localizado no sudoeste do Distrito Federal, próximo às margens da DF-001 e DF-480, antes da área urbana do Gama - RA II e faz limite com o Recanto das Emas RA - XV e com o Riacho Fundo RA - XVII, conforme indica as figuras 3 e 4.

Figura 3 - Mapa de Localização do Setor Habitacional Ponte de Terra

\section{MAPA DE LOCALIZAÇÃO DO SETOR HABITACIONAL PONTE DE TERRA}
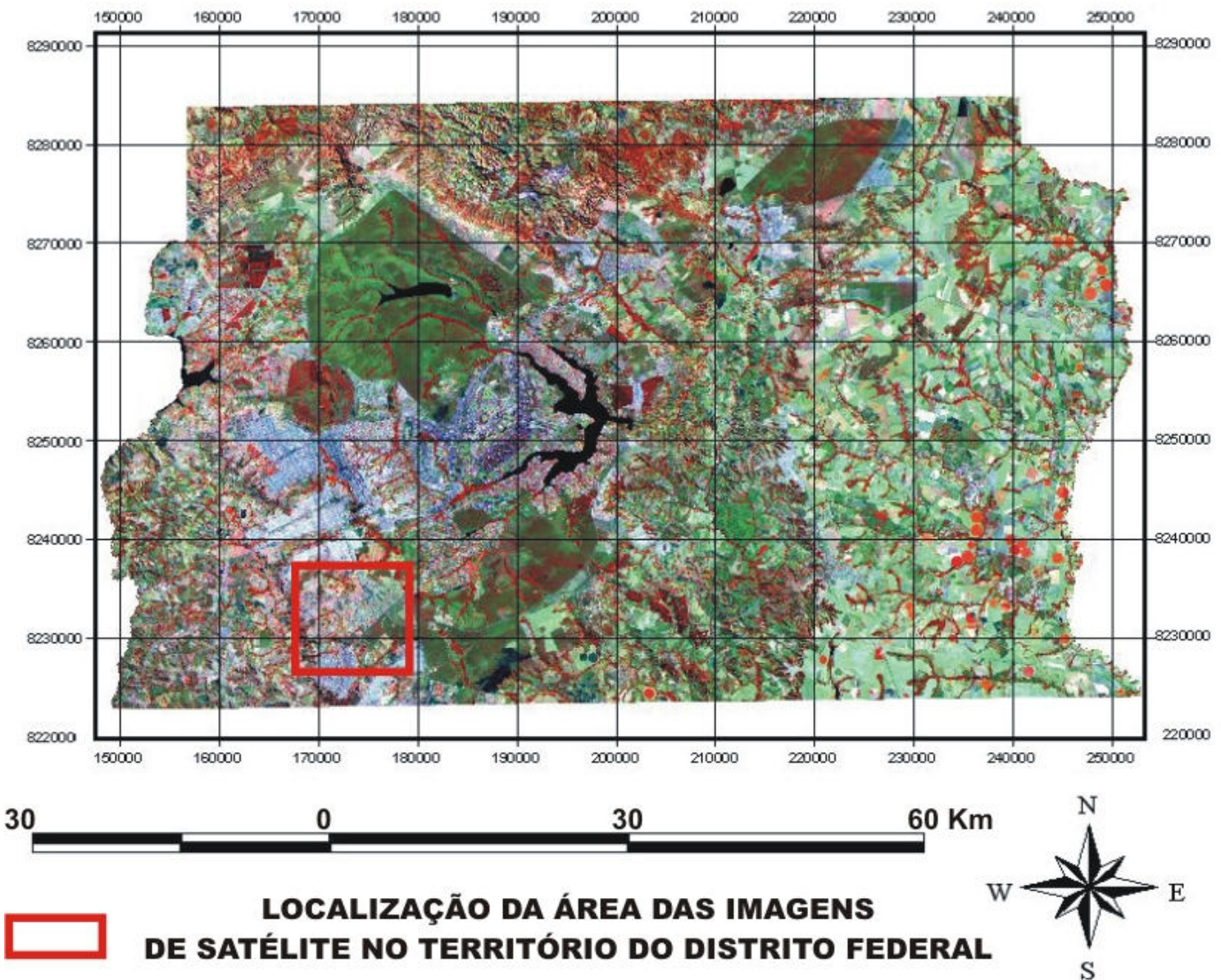

Projeto cartográfico: Sands Xavier da Silva Pereira, 2008. Projeção Cartográfica Universal de Mercator (UTM) ZONA 23S. DATUM SAD-69. Imagem coletada pelo satélite Landsat. Composição 4:3:2 
Figura 4 - Mapa de delimitação do Setor Habitacional Ponte de Terra

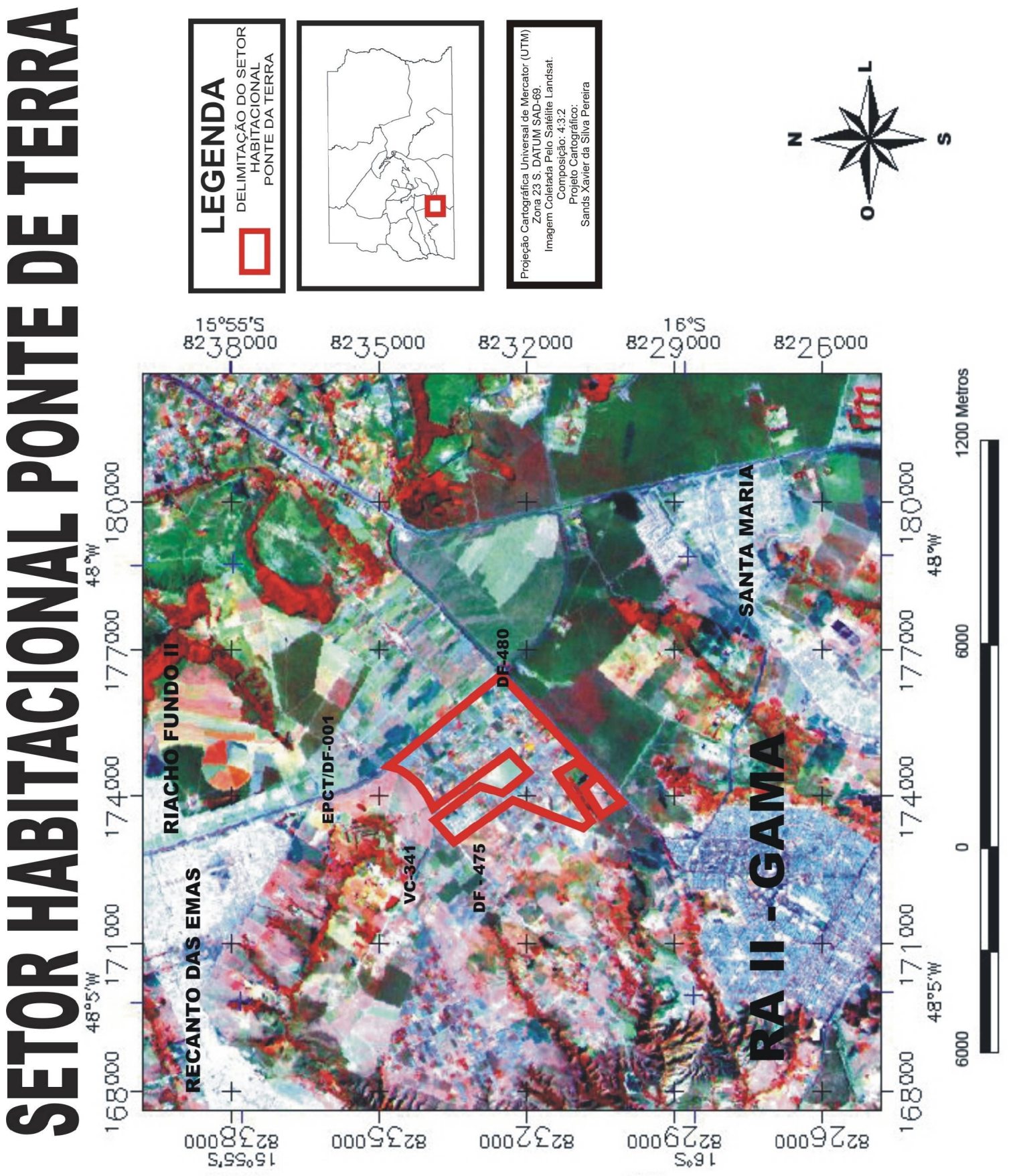


O setor possui uma área de 702,23 ha (setecentos e dois hectares e vinte e três ares), que de acordo com o macrozoneamento do PDOT está dentro de uma Zona Urbana de Dinamização, que compreende uma área já urbanizada prioritária para expansão urbana. Sobrepondo este macrozoneamento o setor está dentro de 02 (duas) Áreas de Proteção de Mananciais, a APM do Córrego Olho D’Água e APM do Córrego Ponte de Terra.

\section{3 - Ocupação do Território}

A ocupação iniciou-se no início da década de 80, a quando os lotes tinham como destinação atividades rurais, principalmente para a produção de alimentos perecíveis, consumível "in natura" para abastecer o Distrito Federal. A presença de atividades rurais praticamente não existe atualmente. As atividades existentes se restringem basicamente a pequenas culturas agrícolas, plantações de frutas, legumes, hortaliças para consumo familiar, culturas para fornecer alimento para animais, como o milho e pastagem, e criação de alguns animais.

No início da ocupação, podemos ver na figura 5, que no ano de 1984 as primeiras glebas já tinham surgido e eram maiores, mas foram diminuindo de tamanho ao longo dos anos 80 e 90 até os dias atuais, mostrando uma maior ocupação urbana. Ainda encontram-se diversos lotes com o tamanho mínimo rural e até maiores, mas a predominância é de lotes menores para servir de habitação.

O setor hoje ainda é pouco habitado, possui poucas construções, mas novos parcelamentos continuam surgindo. Além de construções destinadas a habitações, encontra-se também outros tipos de construções, como, igrejas, alguns prédios 
comerciais (bares, mercados), clubes, casa de eventos e até mesmo pequenas indústrias ligadas atividades rurais próximo da DF-001

Fazem parte do Setor Habitacional Ponte de Terra os parcelamentos, Residencial das Palmeiras, Projeto Agronasa, Residencial Ponte Alta de Cima, Loteamento Ponte Alta de Cima e Park do Gama. Dentro do setor existem 1.606 (mil seiscentos e seis) lotes, sendo que destes 1.086 (mil e oitenta e seis) estão ocupados, compreendendo uma área de 686 ha (seiscentos e oitenta e seis hectares), onde possui 4004 (quatro mil e quatro) habitantes, segundo a SEDUMA(2007). 
Figura 5 - Análise multitemporal da ocupação do território

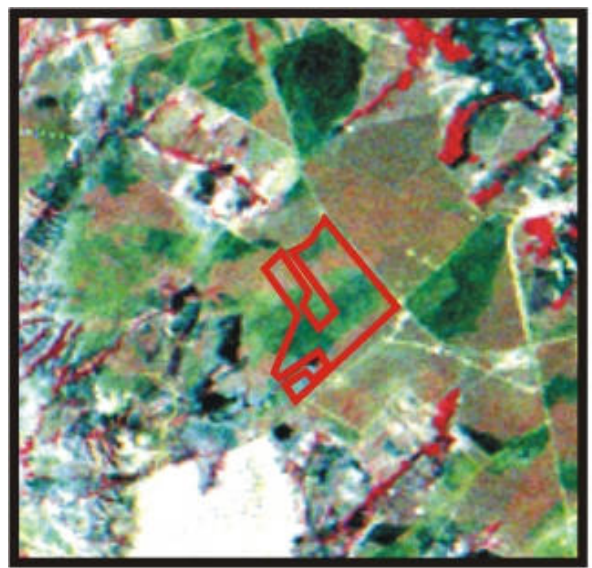

1975

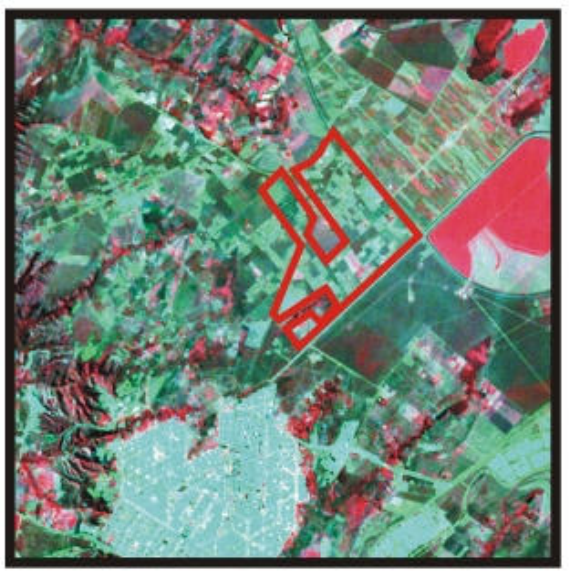

1992

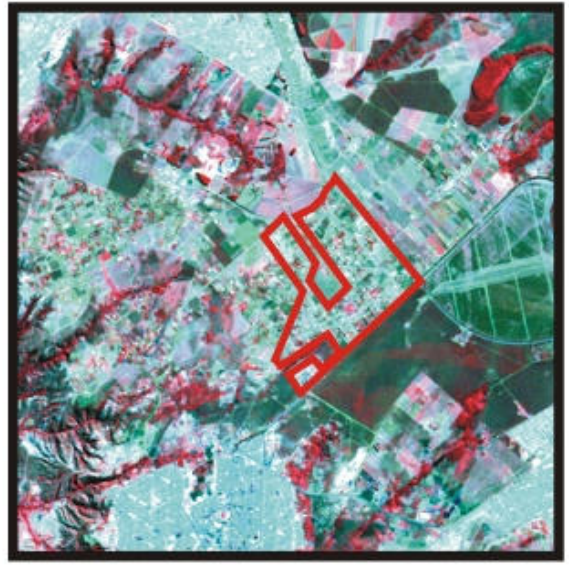

2003

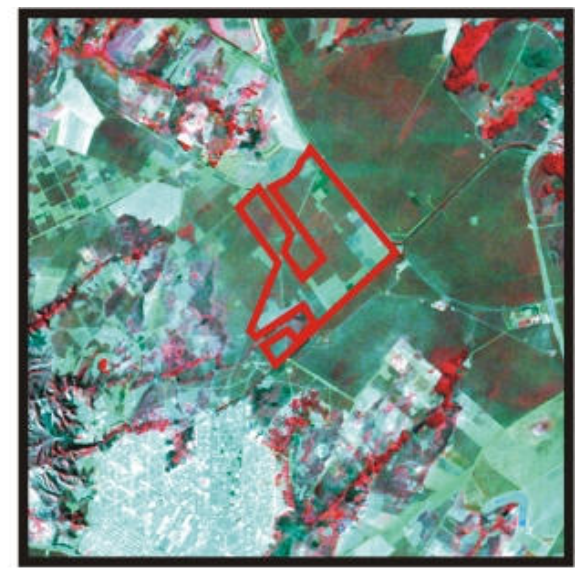

1984

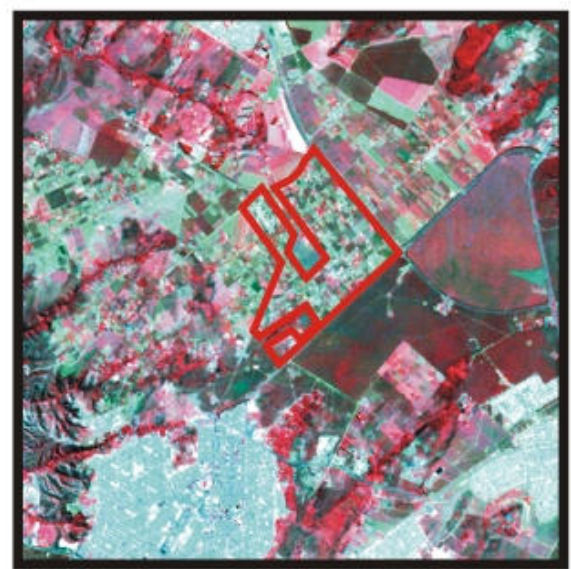

1999

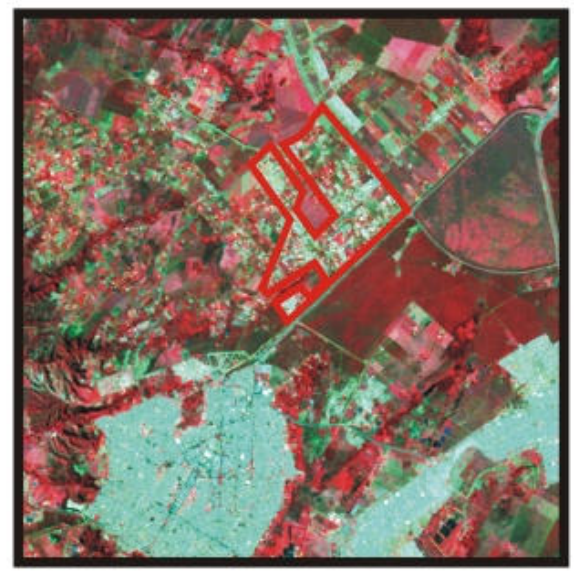

2008

SETOR HABITACIONAL PONTE DE TERRA

Projeto cartográfico: Sands Xavier da Silva Pereira, 2008. Projeção Cartográfica Universal de Mercator (UTM) ZONA 23S. DATUM SAD-69. Imagenm coletada pelo satélite Landsat. Composição 4:3:2 


\section{4 - Caracterização Físico-Ambiental}

\subsection{1 - Geologia}

Dentre os quatros grupos litológicos que compõem o Distrito Federal, o Setor Habitacional Ponte de Terra está localizado no grupo Paranoá, como é possível observar na figura 6. Segundo CAMPOS (2004) compreende cerca de 65\% da área do Distrito Federal e é dividido em sete unidades litoestratigráficas correlacionadas, da base para o topo, com seqüências Q2, S, A, R3, Q3, R4 e PC.

Figura 6 - Mapa Geológico Simplificado da região do Distrito Federal

Mapa Geológico Simplificado da região do Distrito Federal, mostrando os grupos ocorrentes com detalhe para o Grupo Paranoá que representa o dominio mais abrangente do Distrito Federal

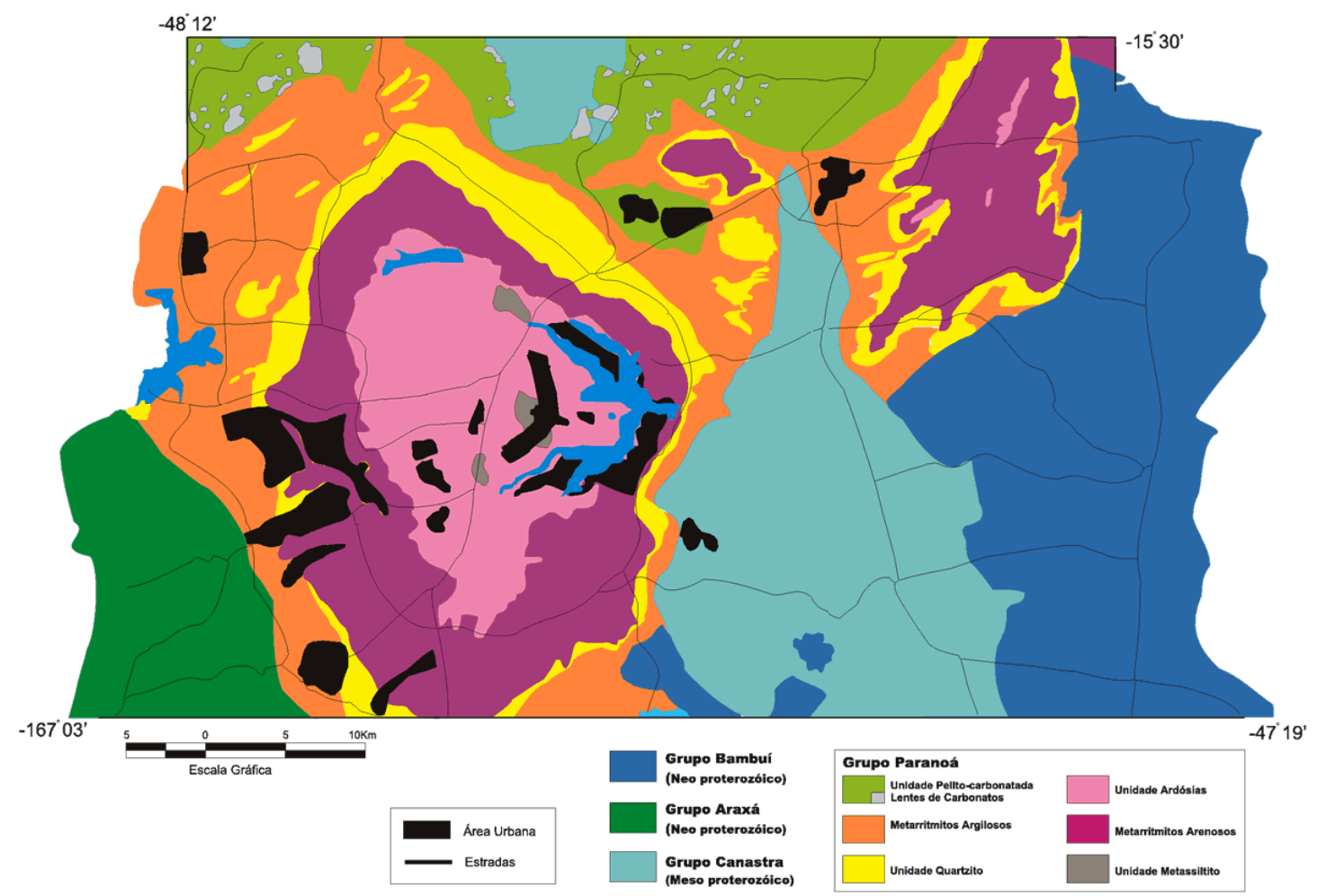

Fonte: SEMARH, 2006 
O setor compreende a porção composta por metarritmitos arenos, que faz parte da unidade R3.

Os metarritmitos da Unidade R3 são caracterizados por intercalações irregulares de quartzitos finos, brancos e laminados com camadas de metassiltitos, metalamitos e metassiltitos argilosos com cores cinza escuro, quando frescos, que passam para tons rosados a avermelhados, quando próximos à superfície. Além do acamamento, podem ser observadas estratificações do tipo sigmoidais e hummockys e marcas onduladas. (CAMPOS, 2004, p.41)

\subsection{2 - Geomorfologia}

O Setor Habitacional Ponte de Terra localiza-se no pediplano ${ }^{3}$ (ou chapada, terminologia popular regional) Contagem do Rodeador, que tem como característica altitudes que variam entre 1.200 metros a 1400 metros. O setor fica em uma das áreas de maior altitude do Distrito Federal, nas cotas 1200 metros a 1250 metros.

A topografia do relevo é homogênea, levemente inclinada no sentido do Córrego Ponte de Terra. A declividade é baixa, chega a menos de $2 \%$ na maior parte da área do setor e nas áreas mais próximas do Córrego Ponte de Terra a declividade varia entre 2\% a $5 \%$.

\subsection{3 - Solo}

O solo encontrado no setor é o Latossolo Vermelho-Escuro. Este tipo de solo é encontrado principalmente no Planalto Central em áreas de vegetação campo cerrado,

\footnotetext{
${ }^{3}$ O pediplano constitui uma superfície de baixo relevo interrompida, ocasionalmente, por elevações residuais (inselbergs). De acordo com Penk, o pediplano representaria o estágio final da evolução de uma paisagem submetida, predominantemente, ao recuo paralelo das vertentes. (GUERRA \& CUNHA, 2003, p.113)
} 
onde o relevo varia de plano a forte ondulado. É um solo de boa resistência a erosões, possui uma boa permeabilidade, drenagem e baixa diferenciação do teor de argila do horizonte A para o B. (GUERRA \& CUNHA, 2003, p.183-182)

\subsection{4 - Vegetação}

A vegetação nativa praticamente não existe, a maior parte foi retirada para dar lugar a atividades agrícolas, principalmente durante a década de 80 e posteriormente dando lugar aos loteamentos urbanos. É comum encontrar lotes como o solo exposto como na foto 1.

Foto 1 - Lote com solo exposto praticamente sem cobertura vegetal

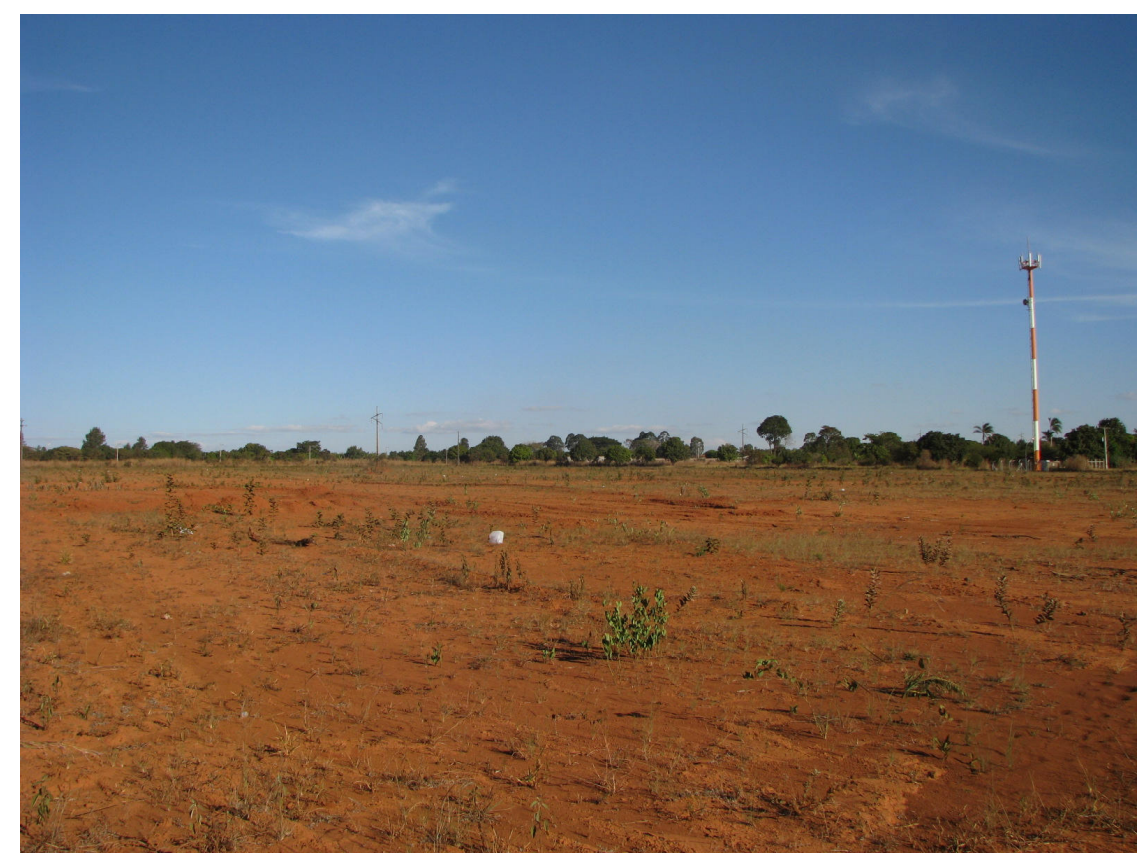

Foto: S. Pereira, 2008

É possível encontrar corredores de vegetação de cerrado e campo cerrado em algumas áreas verdes, junto de espécies invasoras (foto 2). Nas adjacências do limite do setor com a nascente do Córrego Ponte de Terra e o seu curso d'água, é encontrado vereda e mata de galeria (foto 3 ). 
Foto 2 - Presença de espécies nativas e principalmente de gramíneas invasoras

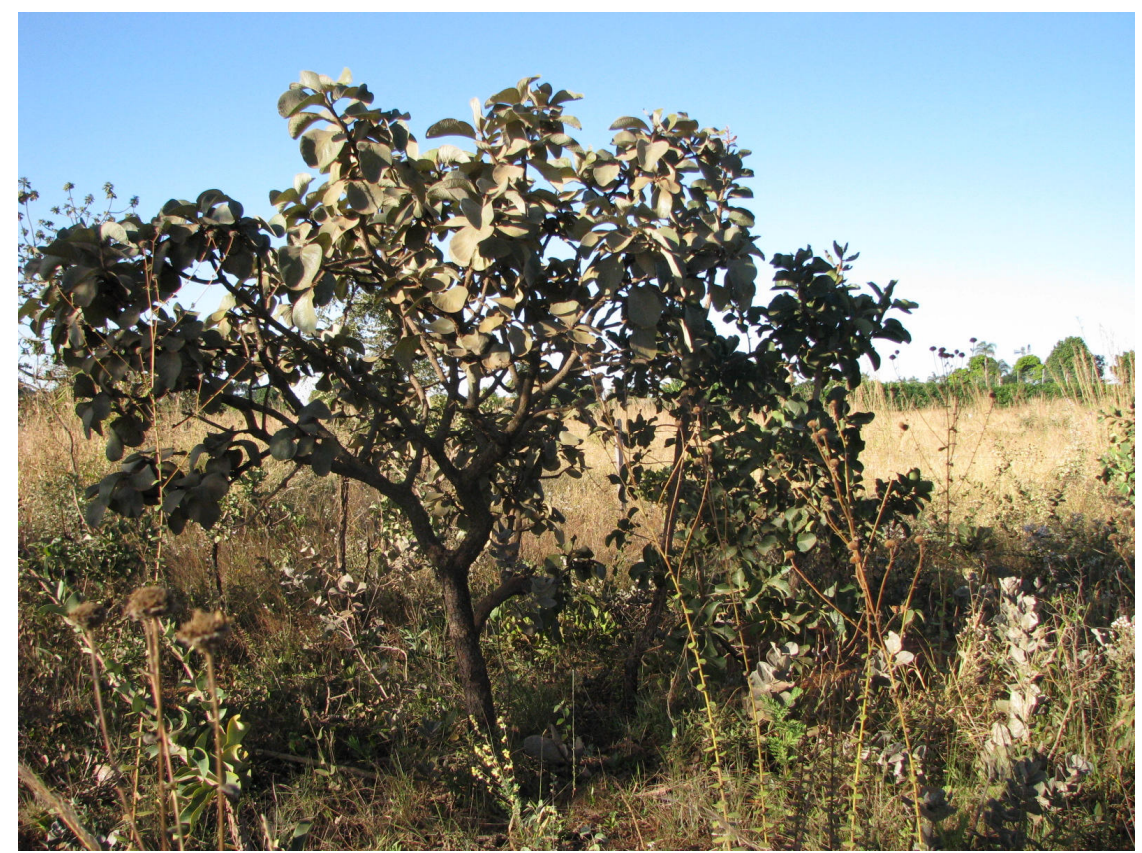

Foto: S. Pereira, 2008

Foto 3 - Mata de galeria do lado esquerdo e vereda do lado direito

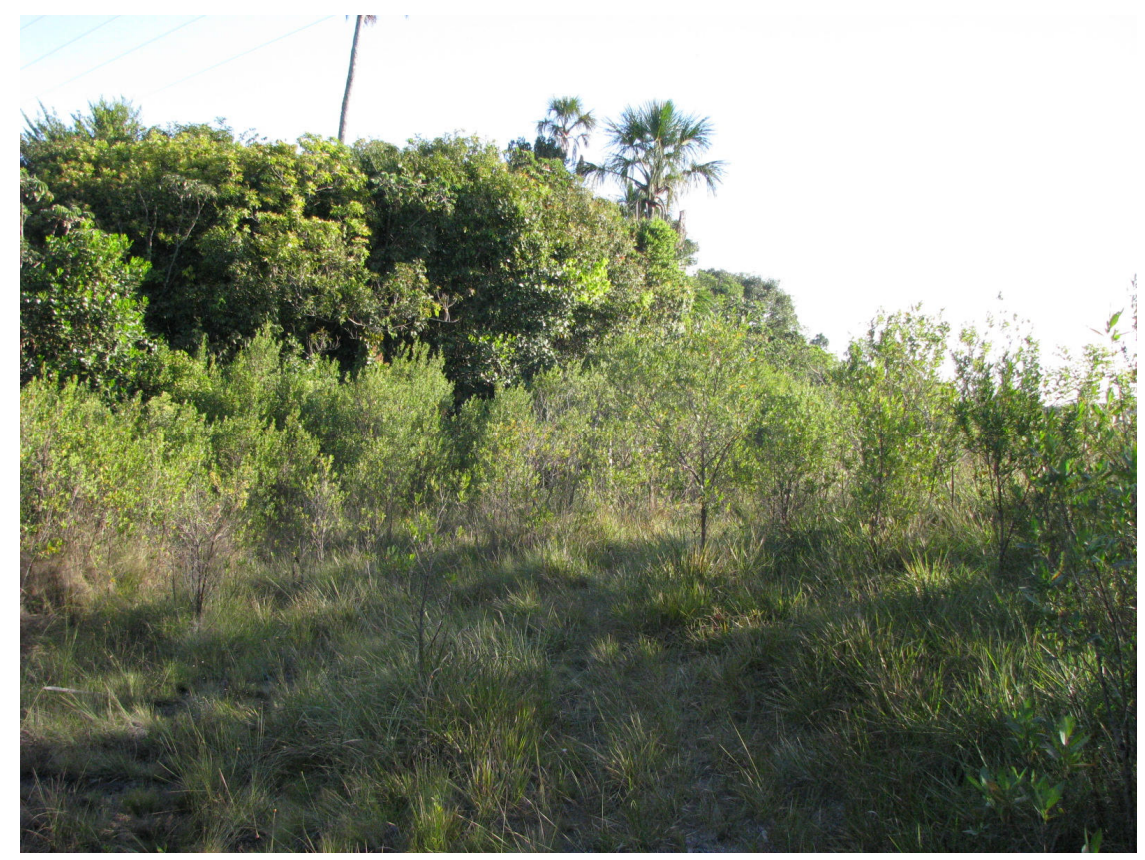

Foto: S. Pereira, 2008 


\subsection{5 - Recursos Hídricos}

O Setor Habitacional Ponte de Terra do Gama-DF, está localizado na APA do Planalto Central, na bacia do Córrego Ponte de Terra e na bacia do Córrego Olho D’Água, que abastecem o Ribeirão Ponte Alta (figura 7). O Decreto $\mathrm{n}^{\circ} 18.585$ de setembro de 1997 regulamentou a criação de Áreas de Proteção de Mananciais - APMs, que tem como objetivo a conservação, recuperação e o manejo das bacias hidrográficas dos córregos que possuem pontos de captações de água destinada ao abastecimento público feito pela CAESB. Cria-se então com o decreto as APMs das bacias dos córregos, Ponte de Terra e Olho D’água.

Os mananciais Ponte de Terra e Olho D’Água fazem parte do Sistema Produtor de Água do Rio Descoberto. Segundo a CAESB (2005), o Sistema Integrado Rio Descoberto possui uma disponibilidade hídrica de 6.614 1/s em uma vazão média de água tratada em 2004 de 4.009 1/s. A captação deste sistema corresponde aproximadamente $62 \%$ de água produzida pela CAESB.

A disponibilidade hídrica das captações Ponte de Terra II e III é de 24 1/s e a captação Olho D’Água é de 47 1/s. Quanto à vazão média de água tratada apenas a captação Ponte de Terra II opera e com 6,7 1/s. 
Figura 7 - Mapa de localização das APMs Ponte de Terra e Olho D’água

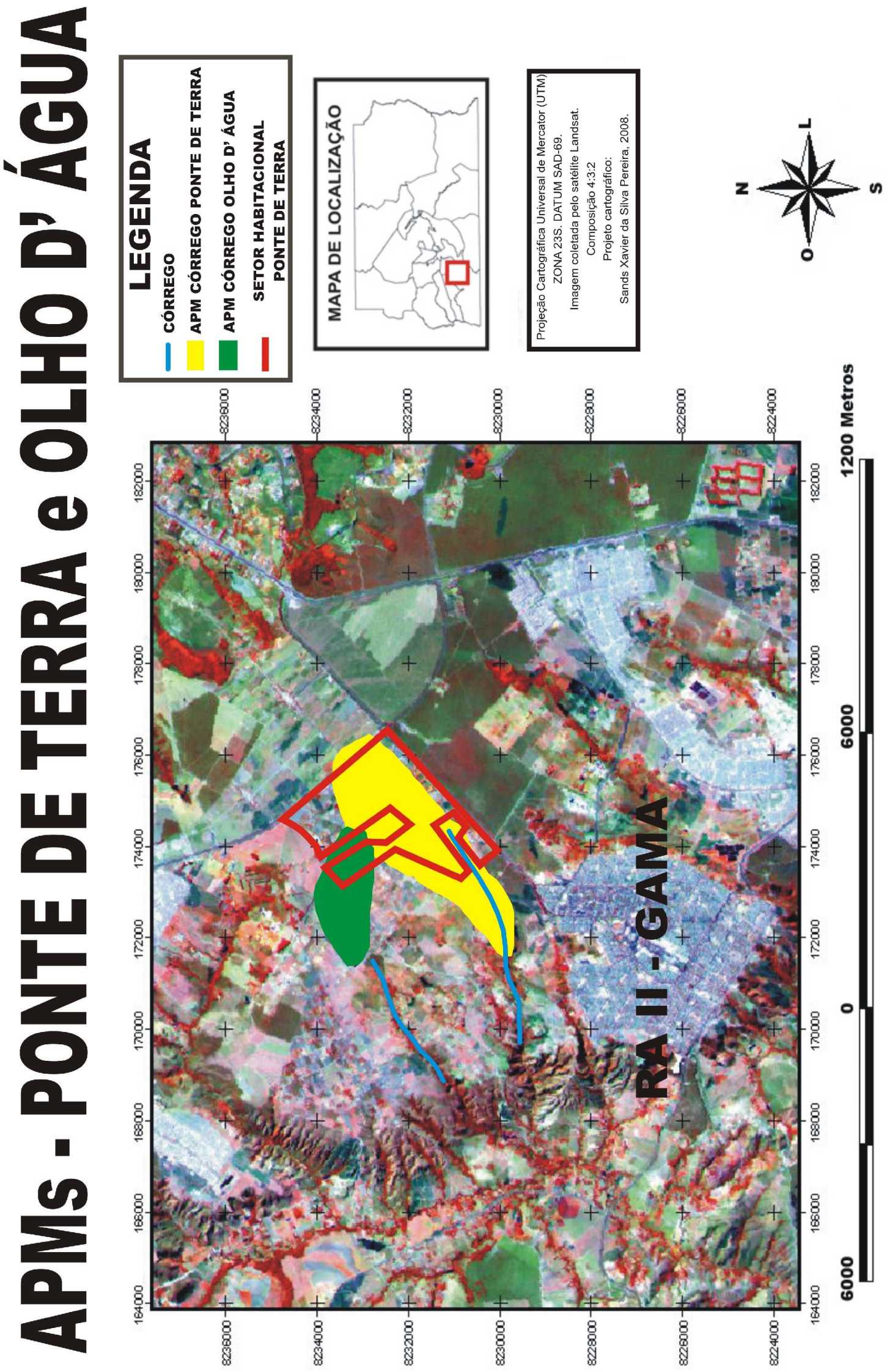




\subsubsection{1 - Captações Ponte de Terra I, II e III}

Segundo a CAESB(2005), a área de captação da bacia do Córrego Ponte de Terra, compreende 9,4 $\mathrm{km}^{2}$. O tipo de captação feita na APM Ponte de Terra ao abastecimento público é por barragem de nível. Das 03 (três) captações deste sistema apenas a captação Ponte de Terra II está operando e em períodos intermitentes, pois seu funcionamento fica comprometido principalmente nos períodos chuvosos por conta da contaminação hídrica. As captações Ponte de Terra I e Ponte de Terra II foram desativadas por conta do comprometimento da qualidade da água.

\subsubsection{2 - Captação Olho D’Água}

A área de captação da bacia do Córrego Ponte de Terra é de $2,3 \mathrm{Km}^{2}$. A captação é feita por barragem de nível. Sua captação encontra-se desativada desde 1999, por problemas operacionais. (CAESB, 2005, p.36;82)

\subsubsection{3 - Contaminação Hídrica}

O surgimento dos loteamentos rurais e urbanos na área de estudo prejudicou e continua prejudicando a qualidade da água para o abastecimento público no Gama. O setor está em uma área com risco de contaminação hídrica de moderado a muito elevado, segundo o mapa "Riscos à contaminação hídrica superficial" (ver anexo I) da SEDUMA (2006).

Nos anos 80, período do qual se deu o surgimento de loteamentos destinados a atividades agrícolas e atividades urbanas na região, deteriorou a qualidade de água (foto 4) devido ao uso inadequado do solo. Os parcelamentos retiraram praticamente toda a vegetação nativa, sendo uma parte desta próxima à nascente do Córrego Ponte de Terra e ao longo do córrego, no limite com o setor habitacional e outras áreas loteadas 
próximas. A vegetação deu lugar ao plantio de capim principalmente próximo à vereda e à mata de galeria, mostrando-se como uma prática agrícola inadequada para o local, como mostra a foto 5 .

Outras ações antrópicas verificadas que comprometem a qualidade da água é a deposição de lixo como mostra a foto 6 e entulho próximo à nascente do Córrego Ponte de Terra, principalmente pelo fácil acesso ao córrego; uso desregulado da água, devido ao abastecimento feito pelos poços artesianos (foto 7) e cisternas localizadas nos loteamentos e nos próprios lotes; deposição de sedimentos nos córregos devido ao desmatamento e o surgimento de vias vicinais próximo a eles; e a falta de um sistema de esgoto, que está comprometendo a qualidade da água infiltrada no lençol freático.

Foto 4 - Água comprometida próximo a captação Ponte de Terra I

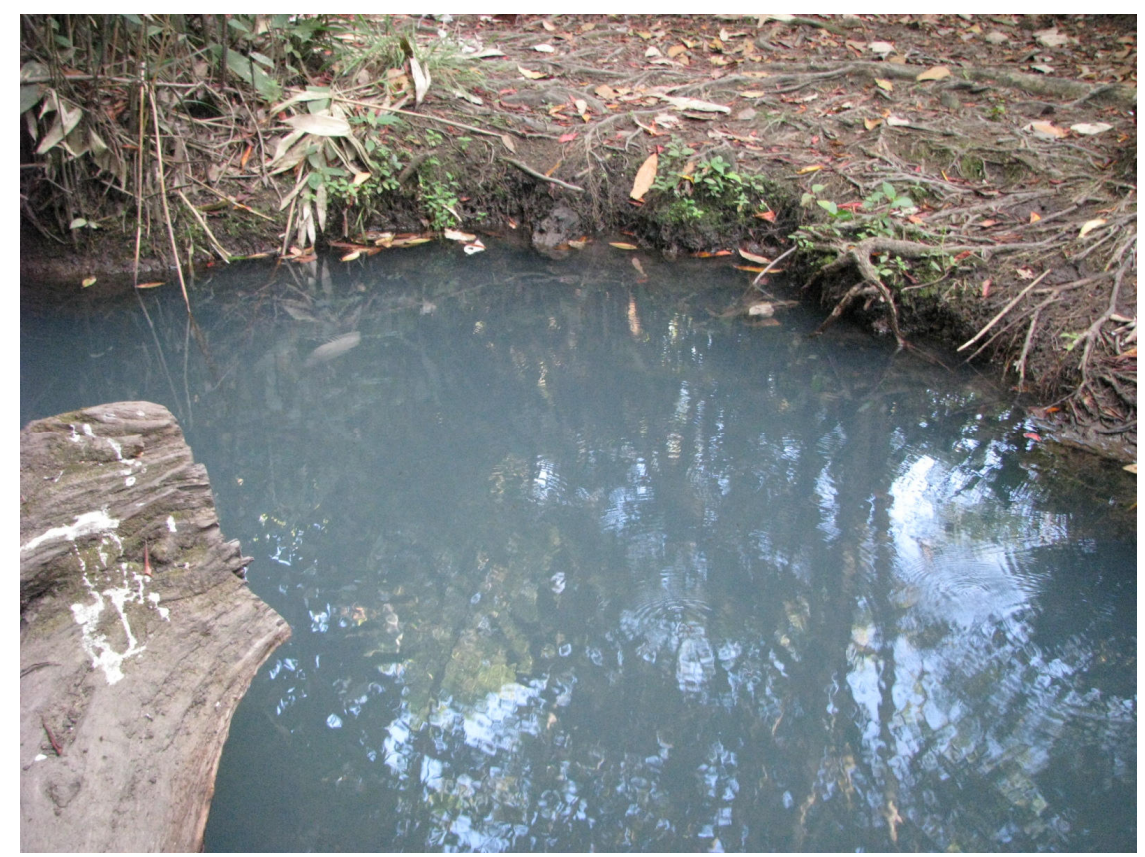

Foto: S. Pereira, 2008 
Foto 5 - Pastagem próxima a vereda e mata de galeria

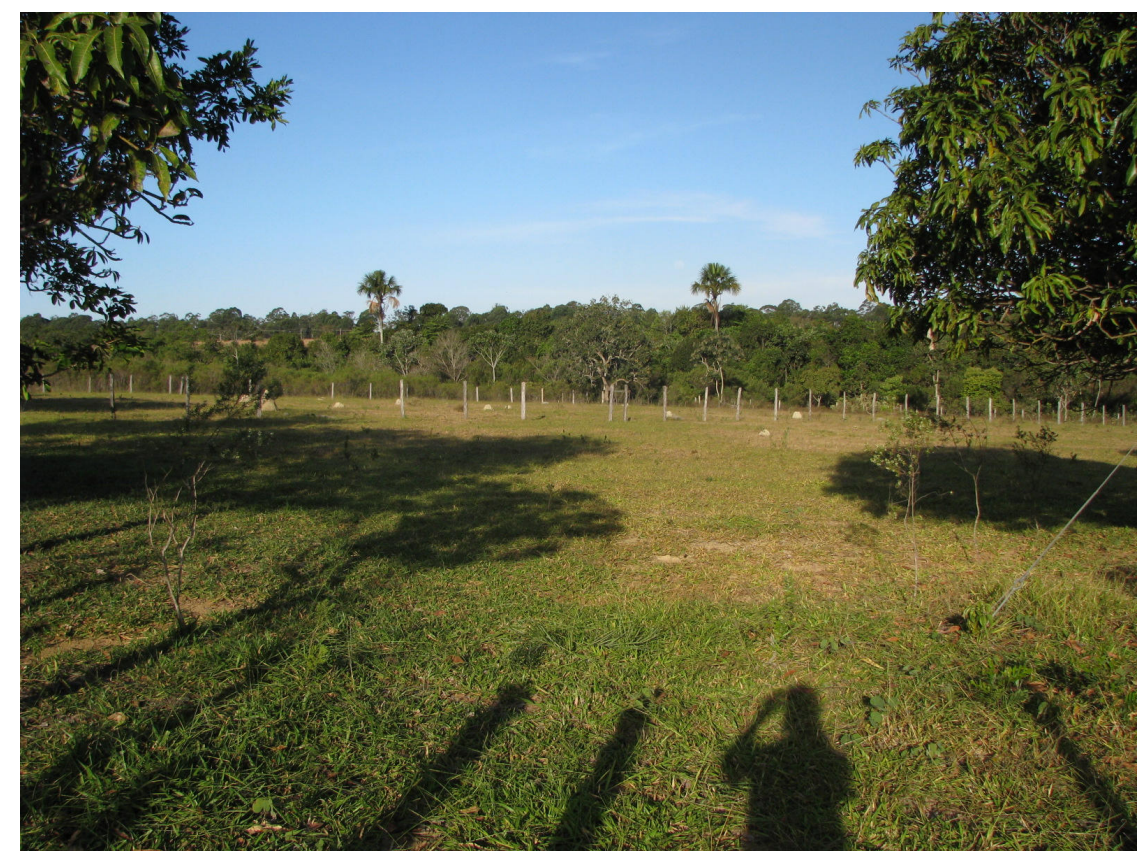

Foto: S. Pereira, 2008

Foto 6 - Presença de lixo próximo ao Córrego Ponte de Terra

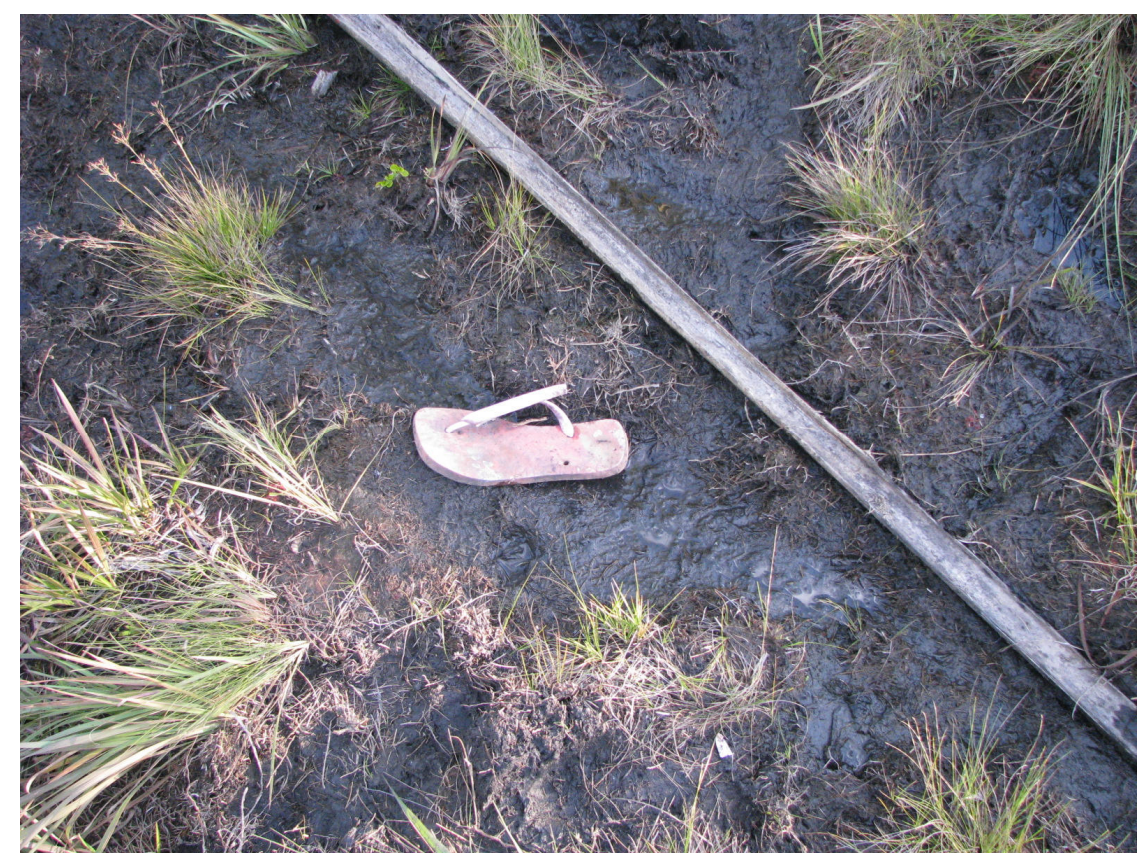

Foto: S. Pereira, 2008 
Foto 7 - Poço artesiano

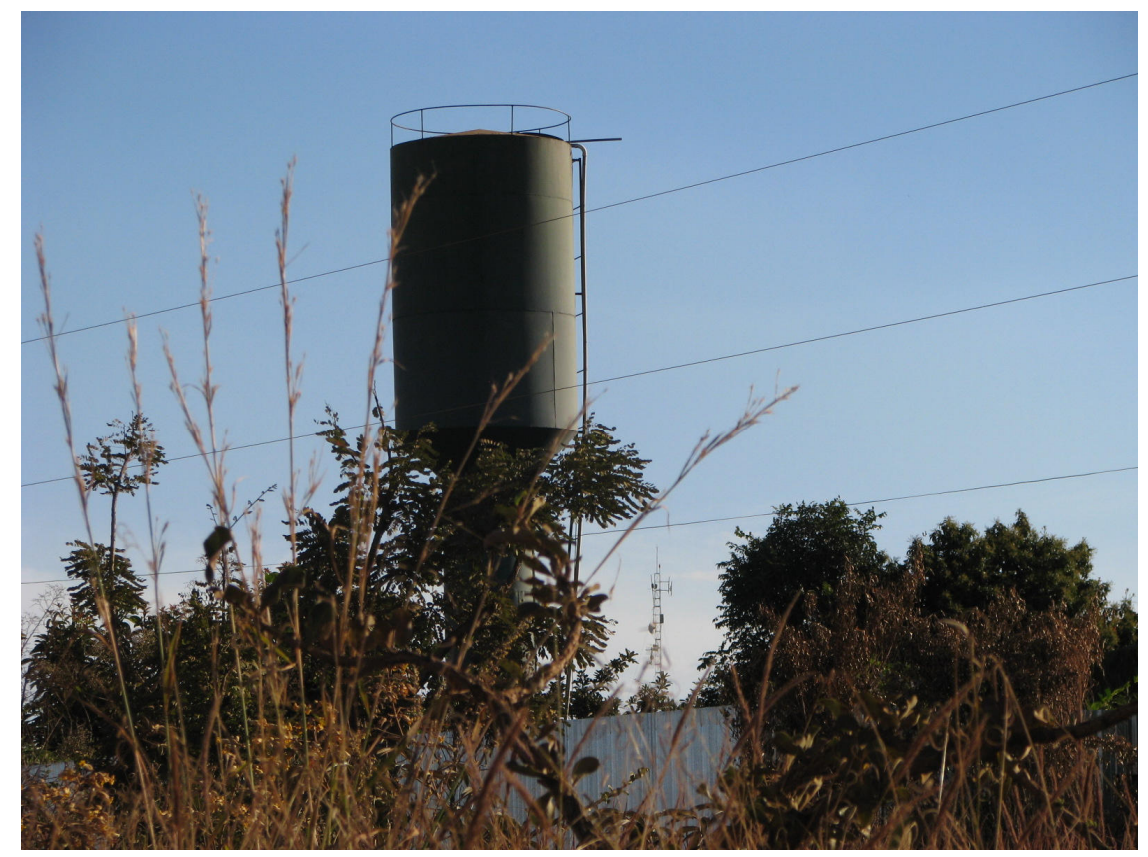

Foto: S. Pereira, 2008

\section{5 - Infra-estrutura}

A infra-estrutura do setor é precária, não possui rede de água, esgoto, nem sistema de águas pluviais. A iluminação pública é insuficiente, parte colocada pela Companhia de Energética de Brasília (CEB) e outra parte pelos próprios moradores, principalmente onde se criaram os chamados "condomínios". Encontram-se trechos de pavimentação asfáltica em alguns loteamentos (foto 8) e em algumas vias, mas predomina a falta de pavimentação das vias (fotos 9 e 10). 
Foto 8 - Via pavimentada

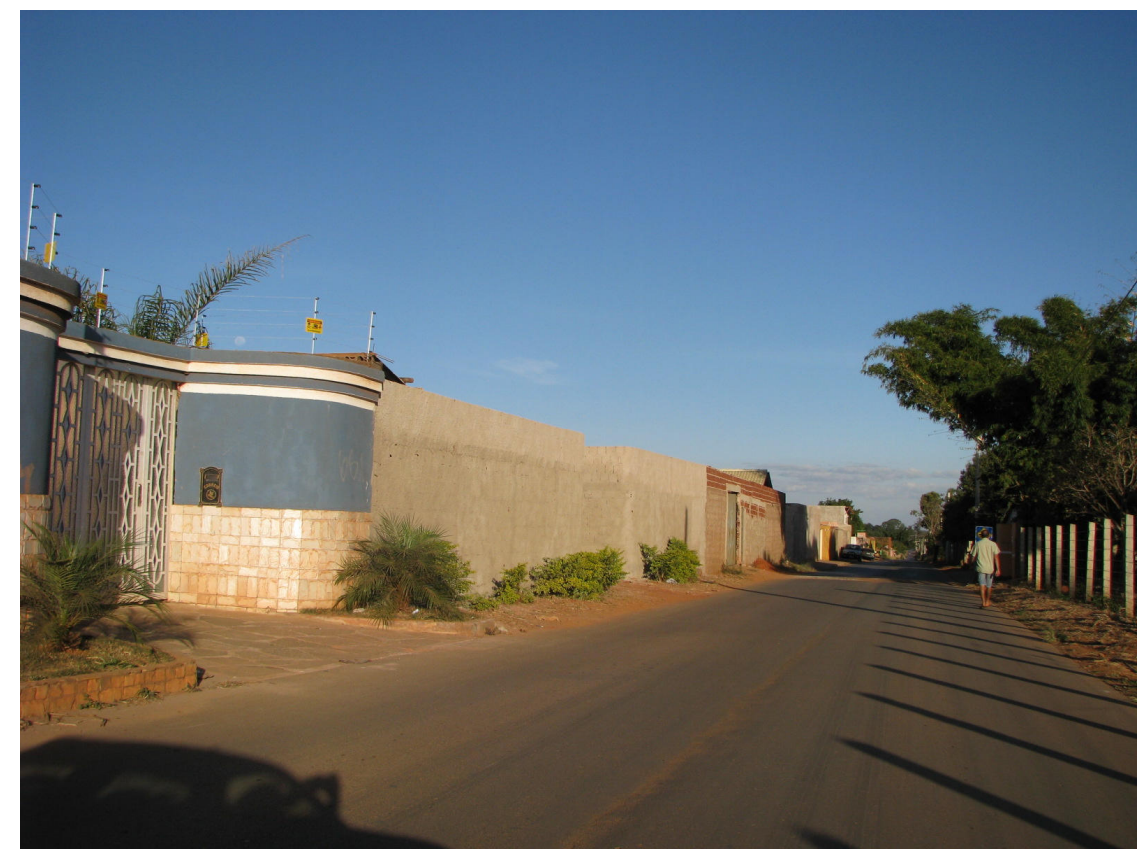

Foto: S. Pereira, 2008

Foto 9 - Falta de pavimentação nas principais vias que cortam o setor

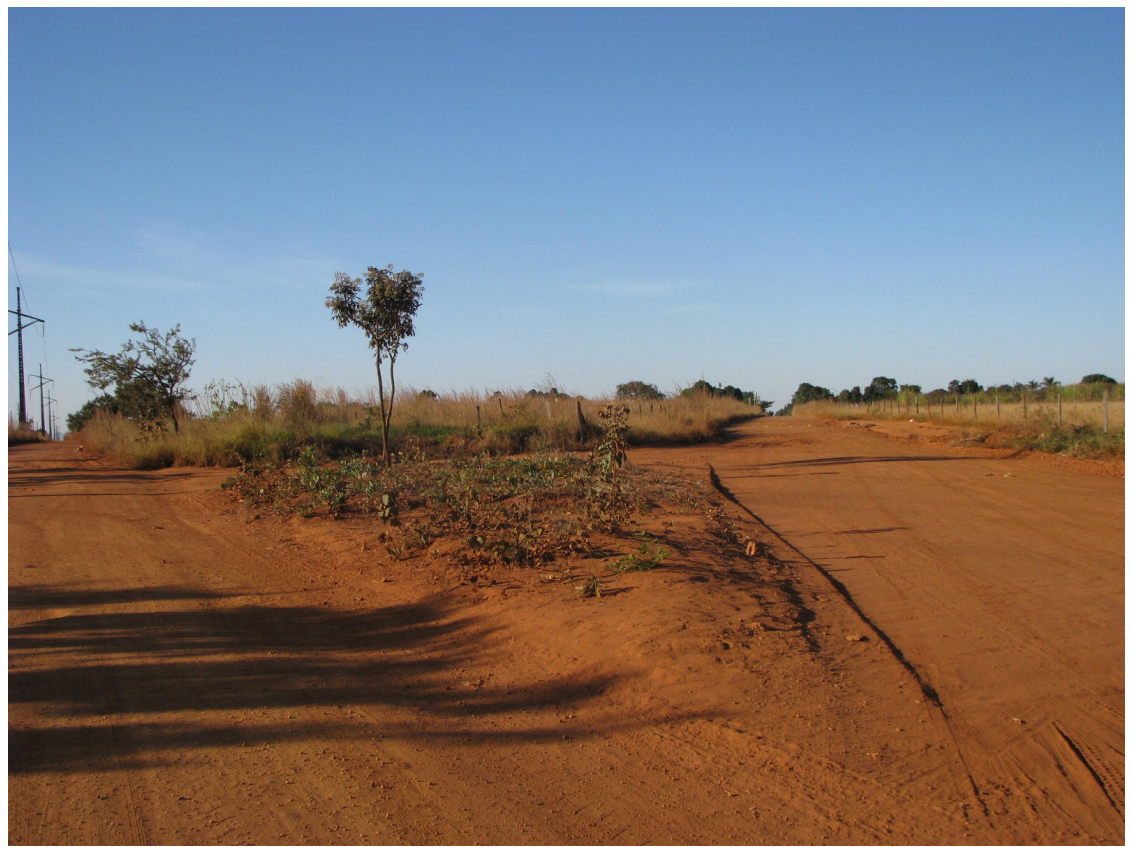

Foto: S. Pereira, 2008 
Foto 10 - Falta de pavimentação nos loteamentos

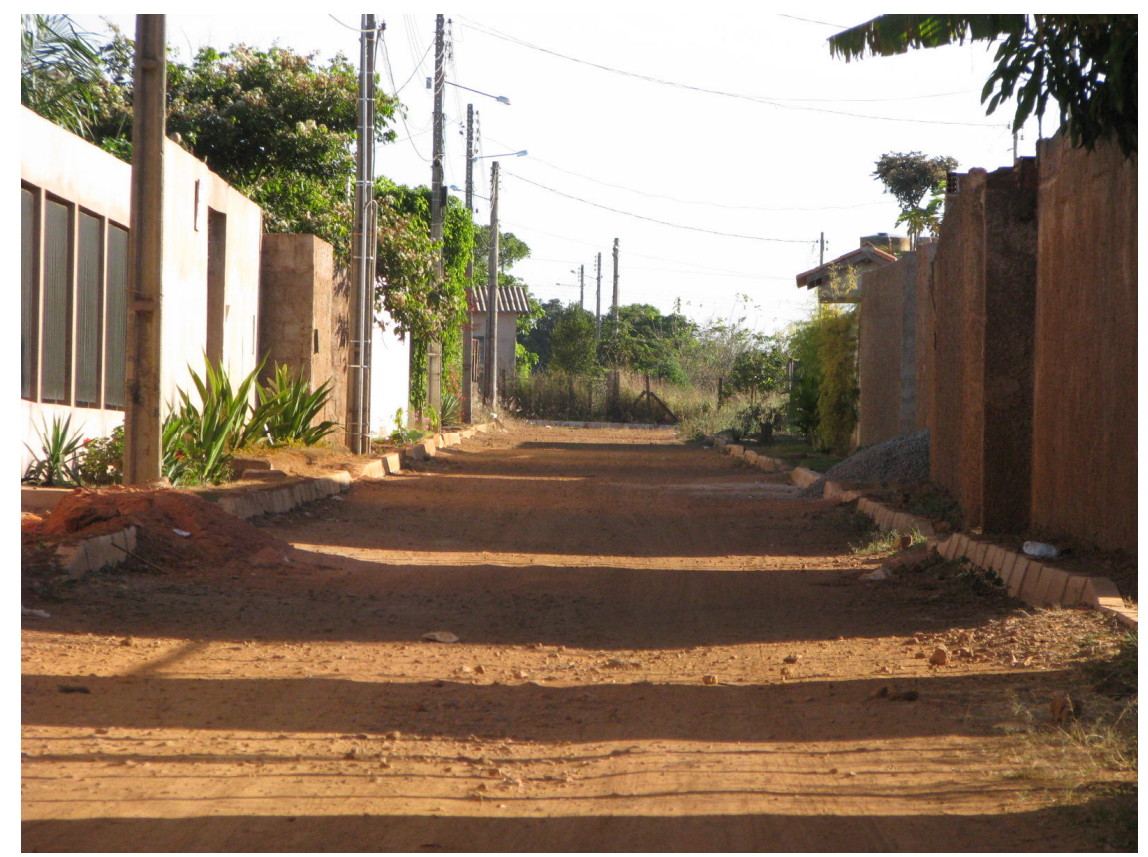

Foto: S. Pereira, 2008

\section{6 - Situação Fundiária}

Hoje o Setor Habitacional Ponte de Terra é um setor urbano que está em área rural, já implementado, onde os loteamentos apresentam sistema viário e divisões de propriedades. Os lotes são informais não regularizados, foram feitos por particulares em área desapropriada da Terracap e em área desapropriada em comum (sem definição se é pública ou particular).

O Termo de Ajustamento de Conduta n002/2007, firmado entre o Ministério Público do Distrito Federal e Territórios e o Governo do Distrito Federal para ajustar os procedimentos de regularização dos parcelamentos de solo para fins urbanos implantados de forma ilegal no Distrito Federal, tratou em uma das considerações termo, onde foi noticiado a grilagem de terras públicas rurais em curso, onde continua a criação de novos parcelamentos e de venda dos lotes como pode-se verificar na foto 11 . 
Foto 11 - Anuncio de venda de lotes no Setor Habitacional Ponte de Terra

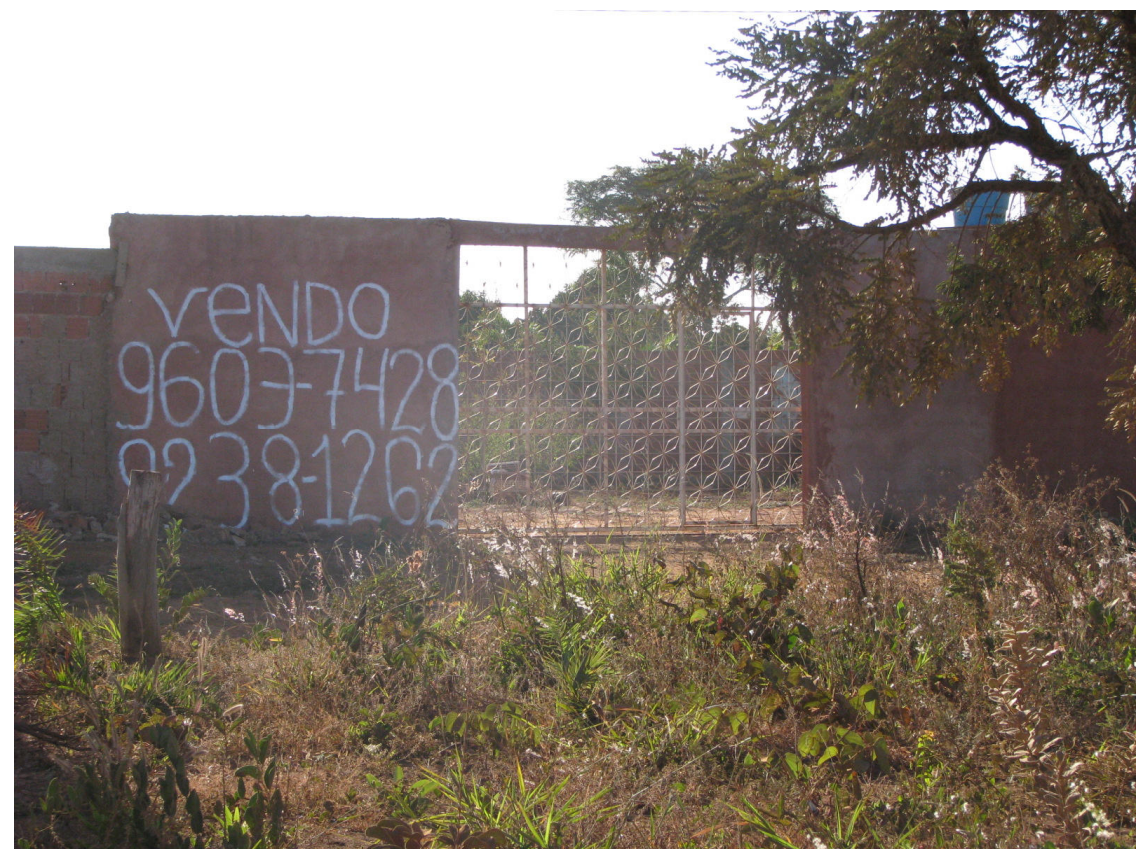

Foto: S. Pereira, 2008

\section{7 - Propostas do Governo Para o Setor Habitacional Ponte de Terra}

A proposta de revisão do PDOT é de destinar $15 \%$ da área total do setor para equipamentos comunitários, urbanos e áreas verdes. A densidade bruta estipulada para o setor será de 30 habitantes/ha, considerada de baixa densidade. Para o tamanho dos lotes urbanos será de no mínimo $125 \mathrm{~m}^{2}$ e máximo de $2.500 \mathrm{~m}^{2}$.

Propõe inserir o setor em uma Zona de Contenção Urbana, que terá como objetivo criar uma zona de amortecimento entre o uso urbano intenso e a Zona Rural de Uso Controlado, onde "se pretende garantir a preservação e manutenção das suas características naturais por meio do estabelecimento de parâmetros de uso e ocupação do solo restritivo" (GDF, 2007). Nessa zona se destaca: proibição de novos parcelamentos com lotes de "condomínios" inferiores a 10 ha, compatibilização do uso 
urbano com conservação dos recursos naturais, conciliar o uso habitacional com o agrícola.

Para se regular o uso da terra, propõe: área mínima dos lotes de 10 ha; ocupação que respeite os limites: $24 \%$ do total de lote do condomínio para unidades autônomas e 76\% para área de uso comum, sendo 4 unidades habitacionais por hectare; $8 \%$ poderão ser utilizados para equipamentos complementares; recuperar e qualificar áreas degradadas para minimizar os danos ambientais; será exigido do empreendedor projetos de drenagem e sistema de esgotamento sanitário. (GDF, 2007)

É previsto a criação de um Pólo Multifuncional, o PM1, que abrangerá o Setor Habitacional Ponte de Terra, Setor Habitacional Catetinho, Expansão do Riacho Fundo II, Colônia Agrícola Catetinho e Núcleo Rural Casa Grande, que terá como objetivo ofertar serviços essenciais de consumo próximo à população residente vizinha. Serão implantados também usos com ênfase em equipamentos de pequeno porte de saúde, abastecimento, cultura, esporte e lazer, dando prioridade aos equipamentos de saúde pública e comércio de bens e serviços associados à habitação. 


\section{4 - CONSIDERAÇÕES FINAIS}

Brasília sempre teve problemas com a falta de moradias, principalmente pela concentração de terras em poder do Estado, fazendo com que tenha pouca disponibilidade de terras para atender ao crescimento da demanda habitacional e pelo fato dessa concentração fazer com que a mesma seja muito cara. Além dessa concentração de terras com o Estado, Brasília possui um "engessamento" quando se trata de áreas urbanas destinadas para a expansão da cidade. As áreas de dinamização urbana muitas são do próprio Estado, mas que já estão ocupadas por pessoas que não possuem títulos da terra, sendo adquiridos lotes de forma ilegal, tendo ou não conhecimento das ilegalidades, mas que alimentam futuramente o desejo de que seja regularizada a situação do seu lote ocupado. Dessa ilegalidade, parte é motivada pelo baixo preço da terra, já que são muito mais baratos que os ofertados pela Terracap ou mesmo por particulares que possuem lotes regularizados.

Percebe-se que a falta de oferta de espaços destinados a moradias pelo Estado faz com que tenhamos a proliferação de loteamentos clandestinos espalhados por toda a cidade. Surge daí a "grilagem" de terras em Brasília que continua presente mesmo sendo noticiado na imprensa e o governo tendo conhecimento do problema. O Setor Habitacional Ponte de Terra que foi estudado sofre desse problema. É muito presente a venda de lotes neste setor e o Estado é o dono das terras, que em um momento anterior autorizou uma ocupação com fins rurais para algumas pessoas através da posse de terra, mas que em um momento posterior deixou que essas pessoas criassem loteamentos clandestinos urbanos, mostrando que foi ineficiente em fiscalizar. 
O setor estudado está dentro de duas APMs, onde os mananciais até algum tempo atrás tinham a importância em abastecer a cidade-satélite do Gama e hoje estão seriamente comprometidos, fazendo com que percam a sua importância na questão do abastecimento. Vemos também que a finalidade de apenas criar leis para preservar ambientalmente certas áreas e conter o crescimento dos loteamentos rurais e urbanos, sem os órgãos do Estado atuando em conjunto na fiscalização, não traz muitos resultados positivos, fazendo com que a questão ambiental fique em segundo plano.

A criação do Setor Habitacional Ponte de Terra é irreversível, os loteamentos que compõem o setor já estão implementados e já havia uma tendência de ocupação da área por estar em uma Zona de Dinamização Urbana apesar de estar em APMs e não atender às normas ambientais a que se destina a área. A proposta de criar esse setor vem a dar uma certa regularização para que o Estado possa traçar estratégias de ordenamento territorial, mas os problemas ambientais gerados por esse tipo de ocupação deverá ser intensificado, além de estimular mais a ocupação no local.

Cabe também ao GDF resolver a questão fundiária do setor, já que a maior parte pertence à Terracap e de uma forma que impeça novos loteamentos urbanos em terras públicas. Para a questão dos loteamentos clandestinos ser solucionada "será preciso considerar três condições: a eficácia da lei, a intenção governamental e a união dos esforços da Administração Pública, iniciativa privada e comunidade" (MALAGUTTI, 1999, p.60-61). Nisto também o Estado precisa se antecipar ao problema habitacional, tratar mais do planejamento da cidade, repensar a política habitacional. Para Gouvêia:

\footnotetext{
A solução para essas questões no âmbito da política habitacional é desenvolver uma oferta paulatina de habitações, constituídas da demanda vegetativa e acrescida da demanda média, objeto da migração, desenvolvendo uma oferta a mais diversificada possível, buscando o atendimento da peculiar demanda do Distrito Federal, que se destaca pela diversidade cultural e renda. (GOUVÊIA, 1999, p.263)
} 
Os loteamentos clandestinos trazem consigo vários problemas que foram verificados no trabalho, principalmente os ambientais, onde surgiram por falta de atuação do Estado, principalmente por não ofertar certos tipos de moradias para as diversas classes de renda que encontramos em Brasília e não coibir a mudança de destinação de uso da área por parceladores. 


\section{6 - REFERÊNCIAS}

Brasil. Presidência da República. Decreto de 10 de janeiro de 2002. Cria a Área de Proteção Ambiental - Apa do Planalto Central, no Distrito Federal e no Estado de Goiás, e dá outras providências. Brasília, 2002.

Lei $n^{\circ} 4.504$, de novembro de 1964. Dispõe sobre o Estatuto da terra. Brasília, 10 de novembro de 1964. Disponível em: <http://www.planalto.gov.br/ccivil_03/Leis/L4504.htm>. Acesso em: 05 de julho de 2008.

Lei $\mathrm{n}^{\circ}$ 6.766, de 19 de dezembro de 1979. Dispõe sobre o Parcelamento do Solo Urbano e dá outras Providências. Brasília, 1979.

CAMPOS, José Elói Guimarães. Hidrogeologia do Distrito Federal: bases para a gestão dos recursos hídricos subterrâneos. In Revista Brasileira de Geociências. 34(1): 41-48, março, 2008.

CAMPOS, Neio Lucio de Oliveira. A segregação planejada. In. PAVIANI, Aldo (org). A conquista da Cidade: Movimentos Populares em Brasília. Brasília. Editora Universidade de Brasília, 1991. pp.: 97-113.

CORRÊA, Roberto Lobato. O Espaço urbano. São Paulo, Editora Ática, 1995.

DISTRITO FEDERAL (Brasil). Câmara Legislativa. Relatório Final da Comissão Parlamentar de Inquérito criada através do Ato do Presidente no 626 de 1995 CDLDF, destinada a apurar fatos relacionados com a grilagem de terras públicas do DF. Diário da Câmara Legislativa, 1995.

GDF. CAESB; SIAGUA: Sinopse do Abastecimento de Água do Distrito Federal. Brasília. 2004, 13 ${ }^{\text {a }}$ Ed. Brasília: CAESB, 2005.

Lei Complementar no 17, de 28 de janeiro de 1997. Aprova o Plano Diretor de Ordenamento Terrirorial do Distrito Federal. PDOT e dá outras providências. Brasília, 1997.

Lei Complementar $n^{\circ} 728$, de 18 de agosto de 2006. Aprova do Plano Diretor Local da Região Administrativa do Gama - RA II, conforme o disposto no art. 316 da Lei Orgânica do Distrito Federal. Brasília, 2006.

CODEPLAN. Brasília e sua Região Polarizada. Brasília, 2003.

. CODEPLAN. Distrito Federal - Síntese de levantamento econômico 2006. Brasília, 2006.

.MPU. Termo de ajustamento de conduta $n^{\circ}$. 002/2007. Firmado entre o

Ministério Público do Distrito Federal para ajustar os procedimentos de 
regularização dos parcelamentos de solo para fins urbanos implantados de forma irregular no território do Distrito Federal, e as medidas de fiscalização e repressão destinadas a coibir a grilagem de terras e ocupação desordenada do solo no Distrito Federal. Brasília, 28 de maio de 2007. Disponível em:

<http://www.mpdft.gov.br/publicacoes/TAC_Regularizacao_Fundiaria_Consolidado.pdf> Acesso em: 05 de julho de 2008.

SEDUH. Apresentação do Plano Diretor Local do Gama. Brasília, 2007.

. SEDUH. Aspectos da população e situação dos domicílios no Distrito

Federal. RA II - GAMA. Brasília, 2006.

SEDUH. Diagnóstico Preliminar dos Parcelamentos Urbanos Informais

no Distrito Federal. Brasília, 2006.

SEDUH. Estudo da Demanda Habitacional no Distrito Federal. Brasília. Metroquattro Arquitetura Tecnologia, 2005.

SEDUMA. Plano Diretor de Ordenamento Territorial do Distrito

Federal, Documento Técnico. Brasília, 2007.

GUERRA, Antonio José Teixeira; CUNHA, Sandra Baptista da. Geomorfologia do Brasil. Rio de Janeiro. Bertrand Brasil, 2003.

GOUVÊA, Luiz Alberto. A capital do controle e da segregação social. In. PAVIANI, Aldo (org). A conquista da Cidade: Movimentos Populares em Brasília. Brasília: Editora Universidade de Brasília, 1991. pp.: 75-96.

Brasília: A capital da segregação e do controle social: uma avaliação da ação governamental na área da habitação. São Paulo: ANNABLUME, 1995.

.Uma política habitacional de interesse social para o Distrito Federal. PAVIANI, Aldo (org). Brasília - Gestão urbana: conflitos e cidadania. Brasília: Editora Universidade de Brasília, 1999. pp.: 253-270.

JACCOUD, Luciana. Lutas sociais: Populismo e democracia: 1960/1964. In. PAVIANI, Aldo (org). A conquista da Cidade: Movimentos Populares em Brasília. Brasília. Editora Universidade de Brasília, 1991. pp.: 145-168.

MALAGUTTI, Cecília Juno. Loteamentos clandestinos no Distrito Federal: Caminhos alternativos para a sua aceitação. PAVIANI, Aldo (org). Brasília - Gestão urbana: conflitos e cidadania. Brasília: Editora Universidade de Brasília, 1999. pp.: 5584.

PAVIANI, Aldo. A construção injusta do espaço urbano. In. PAVIANI, Aldo (org). A conquista da Cidade: Movimentos Populares em Brasília. Brasília: Editora Universidade de Brasília, 1991. pp.: 115-142.

Gestão do território com exclusão socioespacial. PAVIANI, Aldo (org). Brasília - Gestão urbana: conflitos e cidadania. Brasília. Editora Universidade de Brasília, 1999. pp.: 197-221. 
Geografia Urbana do Distrito Federal: Evolução e Tendências. Espaço \&

Geografia, Vol.10, № 1 (2007), pp.:1-22

PELUSO, Marília Luíza. O papel das representações sociais do "Comprar a casa" na identificação dos problemas habitacionais. PAVIANI, Aldo (org). Brasília Gestão urbana: conflitos e cidadania. Brasília. Editora Universidade de Brasília, 1999. pp.: 111-132.

Brasília: Do Mito ao Plano, da Cidade Sonhada à Cidade

Administrativa. Espaço \& Geografia, Vol.6, № 2 (2003), 1-29

OLIVEIRA, Washington Candido. Distrito Federal: Paisagem, População

\& Poder. São Paulo. HARBRA, 2006.

QUINTO JUNIOR, Luiz de Pinedo; IWAKAMI, Luiza Naomi. O canteiro de obras da cidade planejada e o fator de aglomeração. In. PAVIANI, Aldo (org). A conquista da Cidade: Movimentos Populares em Brasília. Brasília. Editora Universidade de Brasília, 1991. pp.: 55-73.

RESENDE, Mara. Movimentos de moradores: a experiência dos inquilinos de Ceilândia. In. PAVIANI, Aldo (org). A conquista da Cidade: Movimentos Populares em Brasília. Brasília. Editora Universidade de Brasília, 1991. pp.: 209-230.

RIBEIRO, Gustavo Lins. Acampamento de grande projeto, uma forma de imobilização da força de trabalho pela moradia. In. PAVIANI, Aldo (org). A conquista da Cidade: Movimentos Populares em Brasília. Brasília. Editora Universidade de Brasília, 1991. pp.: 25-53.

SEBRAE. A questão ambiental no Distrito Federal. Brasília. Brasília: Sebrae-DF, 2007.

SOUSA, Nair Heloísa Bicalho. O movimento pró-fixação e urbanização do Núcleo Bandeirante: a outra face do populismo janista. In. PAVIANI, Aldo (org). A conquista da Cidade: Movimentos Populares em Brasília. Brasília. Editora Universidade de Brasília, 1991. pp.: 169-207.

SOUZA, Marcelo Lopes de. ABC do desenvolvimento urbano. Rio de Janeiro, Editora Bertran do Brasil, 2003. 


\section{ANEXO}

\section{MAPA RISCO À CONTAMINAÇÃO HÍDRICA SUPERFICIAL}

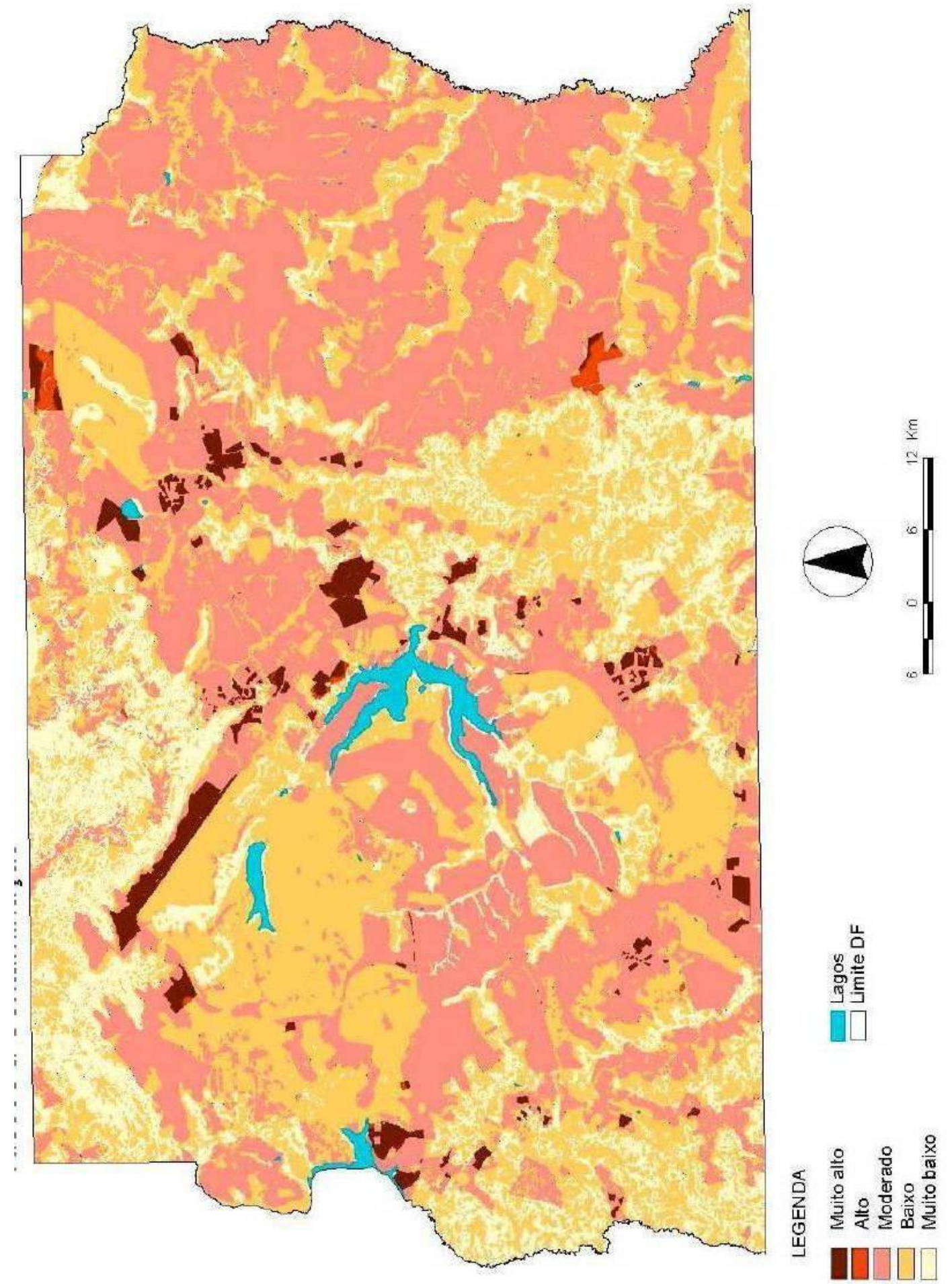

Fonte: SEDUMA, 2006 